\title{
Do Industry Specialist Auditors Add Value In Mergers And Acquisitions?
}

Ho-Young Lee, Yonsei University, South Korea

Vivek Mande, California State University, Fullerton, USA

Jong Chool Park, Old Dominion University, USA

\begin{abstract}
This study examines whether the stock market returns surrounding announcements of mergers and acquisitions (M\&A) are higher for acquiring firms audited by industry specialists. External auditors are uniquely positioned to provide assurance on the financial statements of their acquiring clients both before and after an acquisition. Also, an important aspect of due diligence in M\&A transactions is the external auditor's review of the accounting records, financial statements, internal controls and information systems of the target company. Using a sample of 4,283 M\&A announcements between 1988 and 2011 in the United States of America, we report the results from our main regressions, controlling for all the bidder traits and deal characteristics. We examine incremental effect of audit firm specialization on cumulative abnormal returns. We also measure the effect of audit firm industry specialization in a reduced sample of 3,946 acquisitions after removing all non-Big $N$ auditors. We use Heckman's (1979) two-step procedure to ensure that announcement period return to the size of the audit firm is not driven by the determinants related to auditor choice. Consistent with the idea that industry specialists provide higher quality assurance and possibly superior $M \& A$ advisory services, we find that the stock market returns are higher when acquiring firms are audited by industry specialists.
\end{abstract}

Keywords: Role Of Industry Specialist Auditors; Mergers And Acquisition; Market Reaction; Assurance Services

\section{INTRODUCTION}

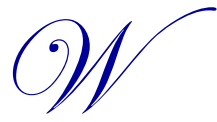
e examine whether stock market returns are higher in corporate acquisitions for acquiring firms audited by industry specialist auditors. We first replicate and confirm results in Louis (2005) showing that acquiring firms' stock market returns are higher when these firms use non-Big 4 auditors. We then consider the role of auditor industry specialization in value creation in M\&A transactions. We find an incrementally significant positive stock market reaction during the five days surrounding M\&A announcements when the acquiring firm is audited by an industry specialist. Our result supports the idea that industry specialist auditors add value to acquiring firms by providing high quality assurance, monitoring, and/or advisory services in the context of M\&A transactions.

Prior research has found that auditors possessing industry specialization (hereafter industry specialists) provide higher quality audits (e.g., Craswell et al. 1995; Hogan and Jeter 1999; and Solomon et al. 1999). Industry specialists reduce the likelihood of earnings management (Kwon et al. 2007), mitigate the negative effects associated with short auditor tenure on earnings quality (Gul et al. 2009), increase the informativeness of earnings (Balsam et al. 2003) and increase the quality of client-firms' disclosures (Dunn and Mayhew 2004). An experimental study also indicates that industry specialists are more competent in diagnosing financial misstatements (Hammersley 2006). Overall, research indicates that industry specialist auditors provide higher quality assurance and monitoring which we argue will also be positively reflected in M\&A transactions of their clients.

Research has examined the effect of audit firm size on various aspects of M\&A transactions. Louis (2005) examines the role of external auditors of acquiring firms on stock prices around M\&A announcements. He finds that acquirers audited by non-Big 4 (Big 4) accounting firms experience higher (lower) cumulative abnormal returns 
around M\&A announcements. He argues that this is because non-Big 4 auditors have a superior knowledge of the local markets in which their clients make acquisitions and, therefore, are able to provide higher quality advisory services. However, since virtually all acquirers use Big 4 auditors, Louis' sample only includes a small number of non-Big 4 auditors. More recently, Xie et al. (2013) document higher abnormal returns around M\&A announcements involving acquired firms that are audited by Big $\mathrm{N}$ auditors. ${ }^{1}$ Their result is consistent with acquirer firms being provided with greater assurance when their targets are audited by the Big N. Golubov et al. (2011) also report that acquirers experience significantly higher M\&A announcement returns when target firms are audited by Big N auditors. The authors state that financial information accuracy is higher when targets are audited by Big N, resulting in better matches of bidders-targets and higher synergies to acquiring firms.

Mergers and acquisitions are complex transactions where conflicts of interests among various stakeholders are often severe and are accompanied by significant wealth transfers from acquirer shareholders to target shareholders along with significant increases in levels of information asymmetry between shareholders and managers (Agrawal et al. 1992; Loughran and Vijh 1997; Rau and Vermaelen 1998; Moeller et al. 2004; Erickson et al. 2012). M\&A transactions also constitute one most complex areas of financial accounting that can create significant uncertainty about firms' reported results for investors.

Prior research suggests that industry specialists provide more monitoring (Dunn and Mayhew 2004) and higher quality services as business transactions increase in complexity (Balsam et al. 2003; Fleming and Romanus 2007; GAO 2008). Consistent with this, using a sample of 4,283 M\&A announcements between 1988 and $2011,{ }^{2}$ we find that the stock market reaction is positive and larger when the acquiring firm is audited by an industry specialist after controlling for the effect of Big $\mathrm{N}$ auditors. Further, we find that the market response is more favorable when industry specialists are used in M\&A deals that are complex and involve more information uncertainty. This study provides new evidence that industry specialist auditors play a significant role in M\&A transactions.

Mergers and acquisitions are highly significant events in the corporate finance world. ${ }^{3}$ M\&A transactions can create synergies from economies of scale and secure greater market power for the acquirer. ${ }^{4}$ However, research has shown that there is tremendous variation in acquirers' abnormal returns to M\&A announcements. ${ }^{5}$ Further, "researchers have been unable to successfully explain much of this variation, partially because the announcement of a takeover reveals information about numerous things" about the transaction (Fuller et al. 2002, p. 1763). By examining the role of industry specialists in M\&A deals, this study increases our understanding of the crosssectional variation in acquiring firms' abnormal returns.

\section{LITERATURE REVIEW AND HYPOTHESES DEVELOPMENT}

Corporate acquisitions generally represent the largest form of investment that companies undertake. While acquisitions have been studied in much detail, there is relatively little evidence on the role of external auditors in these transactions. The auditor is responsible for providing assurance on the combined financial statements including notes associated with the M\&A transactions. As such, the auditor often performs an important role in the transaction as a part of the due-diligence process. The external auditor, for example, reviews the target's accounting records, financial statements, internal controls and information systems. A typical review of the target's financial statements includes ensuring that there are no accounting errors or irregularities and that there is conformity to GAAP. For consolidation and valuation purposes, the target's financial statements are often restated in terms of the acquiring firm's GAAP. The external auditor is also consulted on the tax aspects of the transaction.

\footnotetext{
${ }^{1}$ It would be an interesting to see the effect of target auditors' industry expertise. However, most of our targets are private firms. In addition, our focus is on the acquirer side which makes our different unique compared to Xie et al. (2013) and all others which focus on target auditors or target accounting quality.

${ }^{2}$ Our sample period starts in 1988 because Compustat started providing the detailed non-Big N information in 1988.

${ }^{3}$ Deals are often worth billions of dollars, for example, the merger between SBC Communications Inc. and AT\&T Corp. was worth $\$ 16$ billion dollars. See CFO.com, Deals: The Return of Billion-Dollar M\&A, February 26, 2008 for more examples.

${ }^{4}$ See Bradley et al. 1988; Seth 1990; Healy et al. 1992. Improved efficiency under new management can also be a source of value creation (Manne 1965; Dodd and Ruback 1977; Jensen and Ruback 1983).

${ }^{5}$ See Jensen and Ruback 1983; Singh and Montgomery 1987; Bradley et al. 1988; and Seth 1990.
} 
There have been a few studies that have focused on the role of target auditors in M\&A deals. For example, Xie et al. (2013) argue that Big $\mathrm{N}$ auditors of target firms provide higher quality assurance about the financial statements to acquirer firms than non-Big $\mathrm{N}$ auditors. Big $\mathrm{N}$ auditors of targets also provide greater "insurance" to acquirers in litigation because Big $\mathrm{N}$ auditors have deeper pockets. Using 2,130 completed acquisitions of public targets over 1987-2006, the authors find that targets with Big $\mathrm{N}$ auditors are more likely to become acquisition targets and ultimately get acquired. Using a five-day event window $(-2,+2)$ for 1,909 completed acquisitions in 1996-2008, Golubov et al. (2011) find that acquirers experience significantly positive abnormal returns when their targets are audited by Big 4 auditors. In both studies, however, the sample of target firms is limited to public firms which misses the majority of M\&A transactions consisting of private target firms. Also, in both studies, only a small percentage of target firms are audited by non-Big $\mathrm{N}$ auditors. Xie et al. report that only 6.9 percent of their sample consists of target firms audited by non-Big N auditors, whereas in Golubov et al. this percentage is 9.59.

Louis (2005) argues that mergers and acquisitions is one area where non-Big 4 auditors have a competitive advantage over Big 4 auditors. He suggests that non-Big 4 auditors of acquiring firms have superior knowledge of local markets because they have close and long-time connections with the local business communities and are able to provide more personalized services than Big 4 auditors. Using 3,707 M\&A announcements between January 1980 and December 2002, he finds, consistent with his theory, that acquirers audited by non-Big 4 accounting firms experience higher abnormal returns on the announcement of an acquisition. Virtually all acquiring firms, however, are audited by the Big 4 auditors; in Louis (2005) only 5.5 percent of the acquirers are audited by non-Big 4 auditors.

Prior research has found that, among the Big 4 auditors, those possessing industry specialization provide higher quality audits. Jenkins et al. (2006) and Balsam et al. (2003) report that discretionary accruals are lower and earnings response coefficients are higher for firms audited by industry specialists. Hammersley (2006) reports that compared to other auditors, industry specialists are better able to find errors and accounting irregularities in financial statements of client-firms. Dunn and Mayhew (2005) document that industry specialists increase the quality of client-firms' disclosures. Ahmed et al. (2008) find that the cost of debt and equity capital is lower for firms audited by industry specialists. Mayhew and Wilkins (2003) report that audit fees are higher for industry specialists, which is consistent with industry specialists providing higher quality audits.

The role of industry specialist auditors in M\&A transactions, however, has not been studied. Auditors of acquiring firms are responsible for evaluating measurements and assumptions underlying the combined financial statements in the year of acquisition and thereafter. Auditors must ensure that there are no GAAP violations or accounting irregularities associated with the acquisition. Xie et al. (2013) state that higher quality assurance provided by external auditors lowers financial information risks associated with M\&A deals. Based on prior research showing that industry specialists provide higher quality assurance, we posit that industry specialists provide value to investors by more effectively reducing financial information risks.

There is also greater monitoring and reduced information asymmetry present when the external auditor is an industry specialist (Godfrey and Hamilton 2005; Behn et al. 2008). ${ }^{6}$ Salavei and Moore (2005) suggest that financial restatements and SEC investigations often occur in post-merger periods due to accounting irregularities and improper accounting procedures during acquisitions. Louis (2005) states that a heightened level of scrutiny of the acquirer is inherent in the merger process because of additional disclosure requirements and an increased interest from investors about the acquisition. He also argues that when information asymmetry surrounding the acquirer firm is high, there are greater uncertainties for investors about the potential benefits of an acquisition. The use of industry specialists by acquirers could indicate that the acquiring firms are willing to be subjected to a higher level of monitoring (Balsam et al. 2003), which we posit will be viewed favorably by markets.

${ }^{6}$ Beatty (1989) and Willenborg(1999) also find that higher quality audits mitigate information asymmetry problems to a greater degree than lower
quality audits. Copyright by author(s); CC-BY 
Lastly, we argue that industry specialists are able to provide higher quality advisory services in an acquisition.7 This is because industry specialists have a greater understanding of their clients' industry and business risks (Ahmed et al. 2008). We expect that during the due diligence process, industry specialists will be able to provide better advice to their acquirer-clients about the risks and outcomes of the proposed acquisition. Because M\&A transactions involve a complicated analysis of a target's business and industry risks and synergies to the acquirer, we expect that there will be a higher quality of service from an industry specialist. This is consistent with research showing that as business transactions become more complex, there is an elevation in the role of the industry specialist as advisor (Hogan and Jeter 1999; Solomon et al. 1999; Owhoso et al. 2002). Many acquisitions also involve targets belonging to the same industry as the acquirer which provides industry specialists a comparative advantage in the form of superior industry knowledge.

We argue that for the reasons discussed, stock markets should react positively to M\&A announcements when the acquirer's auditor is an industry specialist. Our hypothesis stated in an alternative form is below:

$\mathbf{H}_{\mathbf{1}}$ : There is a positive association between auditors' industry specialization and cumulative abnormal returns of acquirer firms around $M \& A$ announcements.

\section{RESEARCH MODELS}

Despite extensive research on abnormal returns of acquirers, much variation in the returns remains unexplained. Following Fuller et al. (2002) we compute cumulative abnormal returns using a five-day window (-2, +2 ) where event day 0 is the announcement date of the acquisition. ${ }^{8}$ Following Louis (2005) we use value-weighted returns and estimate the market model parameters over a 200-day period, specifically over event days, -210 to -11 .

To test our hypothesis, the model presented below is estimated:

$$
\begin{aligned}
& A C A R_{i t}=\beta_{0}+\beta_{1} B i g N_{i t}+\beta_{2} A u d s p_{-} T A_{i t}\left(\text { or Audsp_dum }{ }_{i t}\right)+\beta_{3} B / M_{i t}+\beta_{4} R O A_{i t}+\beta_{5} \log (\text { Analyst })_{i t} \\
& +\beta_{6} \log (\text { Tgt_TA })_{i t}+\beta_{7} \text { Stock }_{i t}+\beta_{8} \text { Cash_All }_{i t}+\beta_{9} \text { Pool }_{i t}+\beta_{10} \text { Private }_{i t} \\
& +\beta_{11} \text { NIB }{ }_{i t}+\beta_{12} \text { Inhouse }_{i t}+\beta_{13} \text { Indrel }_{i t}+\beta_{14} \text { Friendly }_{i t}+\beta_{15} \text { Rel_Size }_{i t} \\
& +\beta_{16} L_{L a m b d a}+\text { year dummies }
\end{aligned}
$$
auditor choice. ${ }^{9}$

Variable definitions are presented in Appendix. Lambda: the inverse Mills ratio from the Probit model of

\section{Measuring Industry Specialization}

Prior studies argue that measures of industry specialization based on industry market shares of the auditing firms are better than other types of proxies (Balsam et al. 2003; Dunn and Mayhew 2004; Ahmed et al. 2008; among others). Therefore, we compute the industry market shares of external auditors across two-digit SIC industries and years as follows:

\footnotetext{
${ }^{7}$ Louis (2005) assumes that there are no differences in the quality of M\&A advisory services among the Big 4 audit firms. According to our definition of industry specialization indicator, there are only 6 observations of non-Big $\mathrm{N}$ specialist auditors in our sample. Our finding may therefore be primarily driven by the role of Big $\mathrm{N}$ specialist auditors.

${ }^{8}$ Fuller et al. (2002) find that M\&A announcement dates in Security Data Corporation (SDC) are sometimes off by no more than two trading days from the actual announcement dates. For this reason, they argue that using a 5-day window around the announcement date better captures the announcement effect than 3-day window, without introducing substantial noise into the analysis. As a robustness check we use a 3-day window in our study and obtain qualitatively similar results.

${ }^{9}$ The auditor choice model we use is: $B i g N_{i t}=\mu_{0}+\mu_{1} \operatorname{Ln}\left(A c q_{-} T A\right)_{i t}+\mu_{2}$ Acq_Leverage ${ }_{i t}+\mu_{3}$ Acq_Cash ${ }_{i t}$

$+\mu_{4} R_{-}$Vol $_{i t}+\mu_{5} A c q_{-} E P_{i t}+\mu_{6} A c q_{-}$Regind ${ }_{i t}+\mu_{7} S O X_{i t}+\varepsilon_{i t}$, where Ln $\left(A c q_{-} T A\right)_{i t}$ is the natural logarithm of the acquirer's total assets (in million); $A c q \_$Leverage $_{i t}$ is the acquirer's leverage defined as total liabilities divided by total assets; Acq_Cash ${ }_{i t}$ is the acquirer's cash divided by total assets; $A c q_{-} E P_{i t}$ is the acquirer's earnings-to-price ratio; $R e t_{-} V o l_{i t}$ is a measure of the acquirer's pre-merger stock volatility proxied by the standard deviation of the acquirer's return over the period from 60 to 259 days before the merger announcement; Acq_ Regind $_{i t}$ is a binary variable taking the value one if the acquirer is in a regulated industry (SIC 60-69, and 49) and zero otherwise; and $S O X_{i t}$ is a binary variable taking the value one if the announcement is made in 2003-2011 and zero otherwise.
} 


$$
\text { Audsp_TA } A_{i k}=\frac{\sum_{j=1}^{m} \sqrt{A_{i j k}}}{\sum_{i=1}^{n} \sum_{j=1}^{m} \sqrt{A_{i j k}}}
$$

where,

$$
\begin{aligned}
\text { Audsp_TA } & =\text { industry market share of auditor } i \text { in industry } k ; \\
i & =\text { an index of audit firms; } \\
j & =\text { an index of client firms; } \\
k & =\text { an index of client industries; } \\
\mathrm{n} & =\text { number of audit firms in industry } k ; \\
\mathrm{m} & =\text { number of clients serviced by audit firm } i \text { in industry } \mathrm{k} ; \text { and } \\
\mathrm{A}_{i j k} & =\text { total client assets audited by auditor } i \text { of client } j \text { in industry } \mathrm{k} .
\end{aligned}
$$

Following the logic in Mayhew and Wilkins (2003), we define a proxy of industry specialization using equation (A) based on clients' total assets (Audsp_TA).We also create an industry specialist indicator (Audsp_dum) where Audsp_dum equals one if Audsp_TA is greater than 20 percent during 1988-1997 (Big 6 regime), 25 percent during 1998-2000 (Big 5 regime), and 30 percent during 2001-2011 (Big 4 regime) and is zero otherwise. ${ }^{10}$ Hypothesis 1 predicts positive and statistically significant coefficients on these proxies.

\section{Control Variables}

We control for a standard set of deal and acquirer characteristics used by Louis (2005), among others, that are related to acquirer returns. Rau and Vermaelen (1998) argue that acquirers with high book-to-market ratios $(B / M)$ are less likely to be motivated by hubris in their acquisitions. Louis (2005) finds that acquiring firms with higher $R O A$ experience lower announcement returns. We therefore include acquirer's book-to-market ratios $(B / M)$ and return on assets $(R O A)$ as controls. We use the natural logarithm of analyst coverage (Log(Analyst)) as a proxy for information asymmetry surrounding the acquiring firm. As the level of information asymmetry increases, uncertainty about the acquisition increases which could decrease announcement day returns (Louis 2005). Chang (1998) also finds that M\&A transactions involving higher levels of information asymmetry about the acquirer are associated with lower abnormal market returns. The natural logarithm of target firm size (Log(Tgt_TA)) is included as a control because small targets represent more manageable events In support, Scanlon et al. (1989) and Louis (2004) find that acquirers' abnormal returns decrease with the size of the targets.

It is well known in M\&A literature that acquirers experience significantly negative abnormal returns when they pay for their acquisitions with equity. For example, Travlos (1987) reports negative abnormal returns for firms financing a takeover with common stock and no abnormal returns for those financing with cash. The negative market reaction in stock-for-stock acquisitions is generally attributed to the adverse selection problem in equity issuance (Myers and Majluf 1984; Travlos 1987; Louis 2005). Thus, we include the percentage of the transaction financed with common stock (Stock) and also a binary variable (Cash_All)-- the latter to control for discontinuities around zero in this variable.

An indicator variable representing the pooling-of-interest method (Pool) is included because of research showing that M\&A transactions accounted under the pooling method are motivated by accounting rather than value considerations (Lys and Vincent 1995; Pandit 2006). An indicator variable denoting that the target is a private company (Private) is included because of Chang (1998) and Fuller et al. (2002) who find a positive market reaction to announcements of acquisitions of privately owned firms. Their interpretation is that acquirers capture a liquidity discount when buying private targets. The number of investment banking firms involved in the M\&A transaction $(N I B)$ is included because of Servaes and Zenner (1996) who find that acquirers using the services of investment bankers experience lower acquisition announcement returns. In addition, an indicator variable denoting that no investment bankers were used (Inhouse) is included to control for discontinuities around zero.

\footnotetext{
${ }^{10}$ Using Audsp_dum defined on the single threshold over the entire sample period may bias the results due to the increasing concentration of the audit industry. Following Kwon et al. (2007) we thus use the 20 percent market share threshold during 1988-1997 (Big 6 regime), 25 percent during 1998-2000 (Big 5 regime), and 30 percent during 2001-2011 (Big 4 regime) to construct Audsp_dum. Results are robust to using 20, 25 or 30 percent for all sample years.
} 
An indicator representing industry relatedness of the merging firms (Indrel) is included because of Morck et al. (1990) who show that acquirers experience lower abnormal returns for diversifying (i.e., acquisitions in different industries) than vertical acquisitions. An indicator representing whether the target's attitude to a proposed merger is friendly (Friendly) is included because friendly acquisitions are less costly to acquirers (Schwert 2000). We control for relative size (Rel_Size) motivated by studies by Asquith et al. (1983) and Moeller et al. (2005) who find that bidder announcement returns increase as relative deal size increases. Following Louis (2005) we calculate the inverse Mills ratio (Lambda) and include it in two models in Table 4 in order to control for any possible endogeneity associated with choice of a Big $\mathrm{N}$ auditor. ${ }^{11}$ The definitions of the variables used in our tests are summarized in Appendix.

\section{EMPIRICAL RESULTS}

\section{Sample Selection}

Our sample covers announcements of mergers and acquisitions between January 1988 and December 2011. The sample was drawn from Security Data Corporation's (SDC) database of U.S. mergers and acquisitions. The sample consists of acquisitions of at least 50 percent of the outstanding shares of target firms. ${ }^{12}$ The M\&A transactions in our sample also satisfied the following criteria: (a) the acquirer was a publicly traded company; (b) the method of payment was reported on SDC; (c) the target's total assets were reported on SDC or Compustat; (d) the acquirer's financial statement data on book value, number of shares outstanding, net income, total assets, total liabilities, and auditor code, was available on COMPUSTAT; and (e) the acquirer had the necessary data available on CRSP to compute abnormal return and it also had analyst data on I/B/E/S. There are 4,283 M\&A transactions that met all our selection criteria. Of these, 1,223 (29 percent) acquirer-firms were audited by industry specialist auditors (defined using the proxy Audsp_dum).

\section{Descriptive Statistics}

Table 1 presents summary statistics of our sample acquisitions by announcement year. Beginning in 1991, the number of acquisitions in each year generally increases annually until it reaches its highest level in 1997. Then it drops off significantly in 2002 before rebounding in subsequent years. Table 1 also shows that there is no clustering of the sample in any given year.

\footnotetext{
${ }^{11}$ One may argue that the selection of an industry specialist auditor is not a random choice by the client and thus the determinants of this choice need to be controlled for in the estimation where a dummy industry specialization variable is used. In a reduced sample where only Big $\mathrm{N}$ acquirers are included we control for an endogeneity effect of the choice of industry specialists (Indsp_dum) using the following selection model.

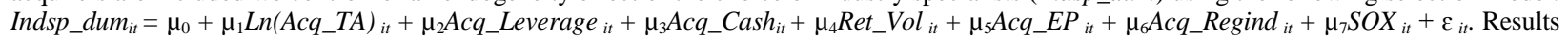
show that the effect of industry specialists remains to be significant even after we control for this endogeneity effect.

${ }^{12}$ When we only include M\&A transactions involving acquisitions of 100 percent of the controlling shares of the target company, the sample size is reduced from 4,283 to 3,827. The effect of industry specialists remains to be significant in this reduced sample.
} 
Table 1. Sample Distribution

\begin{tabular}{|c|c|c|c|c|c|c|c|c|c|c|}
\hline \multirow[b]{2}{*}{$\begin{array}{c}\text { Announcement } \\
\text { Year }\end{array}$} & \multirow[b]{2}{*}{ Total } & \multirow[b]{2}{*}{$\begin{array}{c}\text { Non- } \\
\text { specialists }\end{array}$} & \multirow[b]{2}{*}{ Specialists } & \multirow[b]{2}{*}{$\begin{array}{l}\text { Percent of } \\
\text { specialists }\end{array}$} & \multicolumn{3}{|c|}{ Big N firms } & \multicolumn{3}{|c|}{ Non-Big N firms } \\
\hline & & & & & Total & $\begin{array}{c}\text { Non- } \\
\text { specialists }\end{array}$ & Specialists & Total & $\begin{array}{c}\text { Non- } \\
\text { specialists }\end{array}$ & Specialists \\
\hline 1988 & 57 & 41 & 16 & $28 \%$ & 54 & 39 & 15 & 3 & 2 & 1 \\
\hline 1989 & 69 & 51 & 18 & $26 \%$ & 67 & 49 & 18 & 2 & 2 & 0 \\
\hline 1990 & 50 & 35 & 15 & $30 \%$ & 47 & 32 & 15 & 3 & 3 & 0 \\
\hline 1991 & 66 & 50 & 16 & $24 \%$ & 64 & 48 & 16 & 2 & 2 & 0 \\
\hline 1992 & 151 & 101 & 50 & $33 \%$ & 136 & 86 & 50 & 15 & 15 & 0 \\
\hline 1993 & 210 & 145 & 65 & $31 \%$ & 191 & 127 & 64 & 19 & 18 & 1 \\
\hline 1994 & 232 & 172 & 60 & $26 \%$ & 212 & 152 & 60 & 20 & 20 & 0 \\
\hline 1995 & 165 & 127 & 38 & $23 \%$ & 157 & 120 & 37 & 8 & 7 & 1 \\
\hline 1996 & 139 & 95 & 44 & $32 \%$ & 134 & 90 & 44 & 5 & 5 & 0 \\
\hline 1997 & 326 & 242 & 84 & $26 \%$ & 298 & 215 & 83 & 28 & 27 & 1 \\
\hline 1998 & 293 & 236 & 57 & $19 \%$ & 276 & 221 & 55 & 17 & 15 & 2 \\
\hline 1999 & 264 & 192 & 72 & $27 \%$ & 253 & 181 & 72 & 11 & 11 & 0 \\
\hline 2000 & 223 & 151 & 72 & $32 \%$ & 215 & 143 & 72 & 8 & 8 & 0 \\
\hline 2001 & 156 & 111 & 45 & $29 \%$ & 149 & 104 & 45 & 7 & 7 & 0 \\
\hline 2002 & 105 & 73 & 32 & $30 \%$ & 100 & 68 & 32 & 5 & 5 & 0 \\
\hline 2003 & 130 & 91 & 39 & $30 \%$ & 121 & 82 & 39 & 9 & 9 & 0 \\
\hline 2004 & 100 & 71 & 29 & $29 \%$ & 91 & 62 & 29 & 9 & 9 & 0 \\
\hline 2005 & 115 & 94 & 21 & $18 \%$ & 103 & 82 & 21 & 12 & 12 & 0 \\
\hline 2006 & 204 & 157 & 47 & $23 \%$ & 171 & 124 & 47 & 33 & 33 & 0 \\
\hline 2007 & 323 & 235 & 88 & $27 \%$ & 291 & 203 & 88 & 32 & 32 & 0 \\
\hline 2008 & 278 & 171 & 107 & $38 \%$ & 246 & 139 & 107 & 32 & 32 & 0 \\
\hline 2009 & 217 & 150 & 67 & $31 \%$ & 197 & 130 & 67 & 20 & 20 & 0 \\
\hline 2010 & 224 & 143 & 81 & $36 \%$ & 206 & 125 & 81 & 18 & 18 & 0 \\
\hline \multirow[t]{2}{*}{2011} & 186 & 126 & 60 & $32 \%$ & 167 & 107 & 60 & 19 & 19 & 0 \\
\hline & 4,283 & 3,060 & 1,223 & $29 \%$ & 3,946 & 2,729 & 1,217 & 337 & 331 & 6 \\
\hline
\end{tabular}


Table 2, Panel A presents the summary statistics for the sample according to industry specialization. ${ }^{13}$ About 99.5 percent of specialists and 89.2 percent of non-specialists are Big $\mathrm{N}$ auditors. The mean (median) value of auditor market share (Audsp_TA) is about 19.0 percent. For firms possessing higher growth opportunities (lower $B / M$ ) and more profitable prospects (higher $R O A$ ) a higher quality auditor is used which is consistent with Kwon et al. (2007). Information asymmetry proxied by Log(Analysts) is significantly lower for firms audited by industry specialists (Dunn and Mayhew 2004). We also find that firms with specialist auditors acquire larger targets $\left(\log \left(T g t \_T A\right)\right)$, and are relatively larger in size (Rel_Size). Acquirers with specialist auditors, on average, have a lower percentage of the transaction financed using equity (Stock) and are more likely to finance the transaction entirely using cash (i.e., Cash_All=1). Since equity financing generally indicates an overvaluation of acquiring firm this result indicates that acquirers with specialist auditors face a smaller adverse selection problem (Myers and Majluf 1984). Alternatively, firms audited by industry specialists are more easily able to obtain financing from banks for the acquisition (Ahmed et al. 2008). Acquirers with specialist auditors use the pooling-of-interest method (i.e., Pool=1) less often than the purchase method (Lys and Vincent 1995; Pandit 2006). Firms using specialist auditors have more acquisitions of public companies (i.e., Private $=0$ ) possibly because public companies are more complex and require higher quality audits (Abbott 2006). Firms with industry specialist auditors are more likely to use the services of an investment banker (i.e., Inhouse $=0$ ) and hire more investment bankers $(N I B)$ which is consistent with the idea that investment bankers pressure acquirers to hire higher quality auditors (Balvers et al. 1988). Firms with industry specialist auditors have fewer acquisitions of targets in the same industry (i.e., Indrel=1). A possible reason is that clients of specialist auditors have the largest market share in the industry and therefore making additional acquisitions may be more difficult due to anti-trust regulations. ${ }^{14}$ Mean and median values of all variables are significantly different at least at the 10-percent level of testing across industry specialist and nonspecialist groups.

The Pearson correlation matrix in Table 2, Panel B shows that there is a significant positive correlation between the acquirers' abnormal returns $(A C A R)$ and acquisitions by clients of industry specialists. Consistent with Louis (2005) abnormal return is negatively correlated with the audit firm size $(B i g N)$. The abnormal return is positively correlated with the acquirers' book-to-market ratios $(B / M)$, private acquisitions (Private), and the likelihood that the acquirers use in-house advisers (Inhouse), and negatively correlated with the targets' sizes $\left(\log \left(T g t \_T A\right)\right)$, the acquirers' ROA (ROA), analyst coverage (Log(Analyst)), stock-for-stock acquisitions (Stock), and pooling-of-interest acquisitions (Pool). With the exception of Indrel, Friendly, and Rel_Size, the other variables are also statistically significantly correlated with $A C A R$. Among control variables, the highest correlations are between NIB and Inhouse $(\rho=-0.731)$ and between $\log (T g t+T A)$ and NIB $(\rho=0.616) .{ }^{15}$ Acquisitions by clients of industry specialists are positively correlated with profitability $(R O A)$, analyst coverage ( $\log ($ Analyst $))$, total assets $\left(\log \left(T g T_{-} T A\right)\right)$, financing the transaction entirely using cash (Cash_All), number of investment banks (NIB) and relative size (Rel_Size), and negatively correlated with private acquisitions (Private), the likelihood that the acquirers use in-house advisers (Inhouse), pooling-of-interest acquisitions (Pool), and friendly acquisitions (Frinedly). These correlations are generally consistent with expectations.

\footnotetext{
${ }^{13}$ We winsorize all continuous variables at both extreme 1 percentiles each year to make sure our results are not driven by outliers.

${ }^{14}$ There is a strong positive correlation between NIB and INDREL. This means the effect of industry specialists may be mitigated by hiring of investment banks as M\&A advisors. Therefore, specialists are found more often in diversified M\&As than focused ones. Another explanation will be that by definition clients of specialists have the largest market shares. Thus, it will be more difficult to make industry related acquisitions due to anti-monopoly regulations although specialists may provide higher quality service in industry related acquisitions.

${ }^{15}$ To alleviate concerns about multicollinearity in our regressions, we examine the variance inflation factors (VIFs) for these variables. None of the variables have VIFs greater than five. Also, dropping one or both of the most highly correlated variables does not change our conclusions.
} 
Table 2. Descriptive Statistics And Pearson Correlations

Panel A. Descriptive statistics

\begin{tabular}{|c|c|c|c|c|c|c|c|c|c|c|c|}
\hline \multirow[t]{2}{*}{ 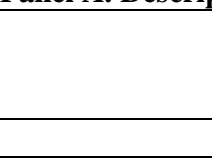 } & \multicolumn{5}{|c|}{$\begin{array}{l}(1) \\
\text { Sampl } \\
=4,283)\end{array}$} & \multicolumn{2}{|c|}{$\begin{array}{c}(2) \\
\text { Specialists } \\
(\mathbf{N}=1,223) \\
\end{array}$} & \multicolumn{2}{|c|}{$\begin{array}{c}(\mathbf{3}) \\
\begin{array}{c}\text { Non-specialists } \\
(\mathbf{N}=\mathbf{3 , 0 6 0})\end{array} \\
\end{array}$} & \multicolumn{2}{|c|}{ (2)-(3) } \\
\hline & Mean & STD & p25 & Median & p75 & Mean & Med & Mean & Med & Mean & Median \\
\hline$A C A R$ & 0.426 & 8.529 & -3.653 & 0.105 & 4.035 & 0.828 & 0.465 & 0.265 & 0.020 & $0.563 * * *$ & $0.446 * *$ \\
\hline$B i g N$ & 0.921 & 0.269 & 1.000 & 1.000 & 1.000 & 0.995 & 1.000 & 0.892 & 1.000 & $0.103 * * *$ & $0.000 * * *$ \\
\hline Audsp_TA & 0.190 & 0.111 & 0.112 & 0.188 & 0.253 & 0.304 & 0.284 & 0.145 & 0.151 & $0.159 * * *$ & $0.133 * *$ \\
\hline$B / M$ & 0.473 & 0.399 & 0.228 & 0.393 & 0.617 & 0.469 & 0.383 & 0.475 & 0.397 & $-0.006 * * *$ & $-0.014 * * *$ \\
\hline$R O A$ & 0.020 & 0.179 & 0.010 & 0.047 & 0.087 & 0.028 & 0.053 & 0.016 & 0.045 & $0.012 * * *$ & $0.008 * * *$ \\
\hline Log(Analyst) & 1.542 & 1.019 & 0.693 & 1.609 & 2.398 & 1.680 & 1.792 & 1.487 & 1.386 & $0.194 * * *$ & $0.405 * * *$ \\
\hline $\log \left(T g t \_T A\right)$ & 4.264 & 2.392 & 2.565 & 4.171 & 5.822 & 4.487 & 4.407 & 4.175 & 4.093 & $0.312 * * *$ & $0.315^{* * *}$ \\
\hline Stock & 33.285 & 42.611 & 0.000 & 0.000 & 80.670 & 29.376 & 0.000 & 34.847 & 0.000 & $-5.470 * * *$ & $-0.000 * * *$ \\
\hline Cash_All & 0.302 & 0.459 & 0.000 & 0.000 & 1.000 & 0.334 & 0.000 & 0.289 & 0.000 & $0.046^{* * *}$ & $0.000 * * *$ \\
\hline Pool & 0.099 & 0.298 & 0.000 & 0.000 & 0.000 & 0.082 & 0.000 & 0.105 & 0.000 & $-0.023 * * *$ & $-0.000 * * *$ \\
\hline Private & 0.441 & 0.497 & 0.000 & 0.000 & 1.000 & 0.422 & 0.000 & 0.449 & 0.000 & $-0.027 * *$ & $-0.000 *$ \\
\hline$N I B$ & 1.433 & 1.279 & 0.000 & 1.000 & 2.000 & 1.513 & 1.000 & 1.400 & 1.000 & $0.113 * * *$ & $0.000 * * *$ \\
\hline Inhouse & 0.477 & 0.500 & 0.000 & 0.000 & 1.000 & 0.459 & 0.000 & 0.485 & 0.000 & $-0.026^{* *}$ & $-0.000 *$ \\
\hline Indrel & 0.499 & 0.500 & 0.000 & 0.000 & 1.000 & 0.464 & 0.000 & 0.513 & 1.000 & $-0.049 * * *$ & $-1.000 * * *$ \\
\hline Friendly & 0.967 & 0.180 & 1.000 & 1.000 & 1.000 & 0.958 & 1.000 & 0.970 & 1.000 & $-0.012 * *$ & $-0.000 * *$ \\
\hline Rel_Size & 114.194 & 549.984 & 3.259 & 9.219 & 33.316 & 122.622 & 10.394 & 110.825 & 8.770 & $11.797 * * *$ & $1.624 * * *$ \\
\hline
\end{tabular}

*,**, and *** denote statistical significance at the 10 percent, 5 percent, and 1 percent levels, respectively, based on one-tailed tests.

Variable definitions are in Appendix. 
(Table 2 continued)

Panel B. Pearson correlation

\begin{tabular}{|c|c|c|c|c|c|c|c|c|c|c|c|c|c|c|c|c|}
\hline & $A C A R$ & (1) & (2) & (3) & (4) & (5) & (6) & (7) & (8) & (9) & (10) & (11) & (12) & (13) & (14) & (15) \\
\hline (1) BigN & $\begin{array}{c}-0.061 \\
(<0.01)\end{array}$ & & & & & & & & & & & & & & & \\
\hline (2) Audsp_TA & $\begin{array}{c}0.031 \\
(0.05)\end{array}$ & $\begin{array}{c}0.169 \\
(<0.01)\end{array}$ & & & & & & & & & & & & & & \\
\hline (3) Audsp_dum & $\begin{array}{c}0.030 \\
(0.05)\end{array}$ & $\begin{array}{c}0.173 \\
(<0.01)\end{array}$ & $\begin{array}{c}0.650 \\
(<0.01)\end{array}$ & & & & & & & & & & & & & \\
\hline (4) $B / M$ & $\begin{array}{c}0.028 \\
(0.07)\end{array}$ & $\begin{array}{c}-0.052 \\
(<0.01)\end{array}$ & $\begin{array}{l}-0.006 \\
(0.72)\end{array}$ & $\begin{array}{l}-0.007 \\
(0.64)\end{array}$ & & & & & & & & & & & & \\
\hline (5) $R O A$ & $\begin{array}{c}-0.061 \\
(<0.01)\end{array}$ & $\begin{array}{c}0.080 \\
(<0.01)\end{array}$ & $\begin{array}{r}0.047 \\
(<0.01)\end{array}$ & $\begin{array}{c}0.030 \\
(0.05)\end{array}$ & $\begin{array}{c}-0.077 \\
(<0.01)\end{array}$ & & & & & & & & & & & \\
\hline (6) $\log$ (Analyst) & $\begin{array}{c}-0.099 \\
(<0.01)\end{array}$ & $\begin{array}{c}0.183 \\
(<0.01)\end{array}$ & $\begin{array}{c}0.119 \\
(<0.01)\end{array}$ & $\begin{array}{c}0.086 \\
(<0.01)\end{array}$ & $\begin{array}{l}-0.220 \\
(<0.01)\end{array}$ & $\begin{array}{c}0.223 \\
(<0.01)\end{array}$ & & & & & & & & & & \\
\hline (7) $\log \left(T g t \_T A\right)$ & $\begin{array}{l}-0.115 \\
(<0.01)\end{array}$ & $\begin{array}{c}0.176 \\
(<0.01)\end{array}$ & $\begin{array}{r}0.155 \\
(<0.01)\end{array}$ & $\begin{array}{c}0.059 \\
(<0.01)\end{array}$ & $\begin{array}{c}0.073 \\
(<0.01)\end{array}$ & $\begin{array}{c}0.168 \\
(<0.01)\end{array}$ & $\begin{array}{c}0.283 \\
(<0.01)\end{array}$ & & & & & & & & & \\
\hline (8) Stock & $\begin{array}{c}-0.128 \\
(<0.01)\end{array}$ & $\begin{array}{c}0.012 \\
(0.44)\end{array}$ & $\begin{array}{c}-0.060 \\
(<0.01)\end{array}$ & $\begin{array}{c}-0.058 \\
(<0.01)\end{array}$ & $\begin{array}{c}-0.083 \\
(<0.01)\end{array}$ & $\begin{array}{c}-0.133 \\
(<0.01)\end{array}$ & $\begin{array}{c}0.053 \\
(<0.01)\end{array}$ & $\begin{array}{r}0.041 \\
(<0.01)\end{array}$ & & & & & & & & \\
\hline (9) Cash_All & $\begin{array}{r}0.027 \\
(0.07)\end{array}$ & $\begin{array}{c}0.068 \\
(<0.01)\end{array}$ & $\begin{array}{c}0.082 \\
(<0.01)\end{array}$ & $\begin{array}{r}0.045 \\
(<0.01)\end{array}$ & $\begin{array}{l}-0.005 \\
(0.72)\end{array}$ & $\begin{array}{c}0.122 \\
(<0.01)\end{array}$ & $\begin{array}{c}0.160 \\
(<0.01)\end{array}$ & $\begin{array}{c}0.092 \\
(<0.01)\end{array}$ & $\begin{array}{c}-0.514 \\
(<0.01)\end{array}$ & & & & & & & \\
\hline (10) Pool & $\begin{array}{c}-0.058 \\
(<0.01)\end{array}$ & $\begin{array}{c}0.056 \\
(<0.01)\end{array}$ & $\begin{array}{c}-0.061 \\
(<0.01)\end{array}$ & $\begin{array}{l}-0.036 \\
(0.02)\end{array}$ & $\begin{array}{l}-0.145 \\
(<0.01)\end{array}$ & $\begin{array}{c}0.056 \\
(<0.01)\end{array}$ & $\begin{array}{c}0.111 \\
(<0.01)\end{array}$ & $\begin{array}{l}-0.007 \\
(0.66)\end{array}$ & $\begin{array}{c}0.481 \\
(<0.01)\end{array}$ & $\begin{array}{c}-0.216 \\
(<0.01)\end{array}$ & & & & & & \\
\hline (11) Private & $\begin{array}{r}0.186 \\
(<0.01)\end{array}$ & $\begin{array}{c}-0.142 \\
(<0.01)\end{array}$ & $\begin{array}{c}-0.112 \\
(<0.01)\end{array}$ & $\begin{array}{l}-0.024 \\
(0.11)\end{array}$ & $\begin{array}{l}-0.006 \\
(0.69)\end{array}$ & $\begin{array}{c}-0.106 \\
(<0.01)\end{array}$ & $\begin{array}{c}-0.235 \\
(<0.01)\end{array}$ & $\begin{array}{c}-0.536 \\
(<0.01)\end{array}$ & $\begin{array}{c}-0.148 \\
(<0.01)\end{array}$ & $\begin{array}{c}-0.165 \\
(<0.01)\end{array}$ & $\begin{array}{c}-0.074 \\
(<0.01)\end{array}$ & & & & & \\
\hline (12) NIB & $\begin{array}{c}-0.147 \\
(<0.01)\end{array}$ & $\begin{array}{c}0.144 \\
(<0.01)\end{array}$ & $\begin{array}{c}0.123 \\
(<0.01)\end{array}$ & $\begin{array}{c}0.040 \\
(<0.01)\end{array}$ & $\begin{array}{l}-0.028 \\
(0.07)\end{array}$ & $\begin{array}{c}0.082 \\
(<0.01)\end{array}$ & $\begin{array}{c}0.297 \\
(<0.01)\end{array}$ & $\begin{array}{c}0.616 \\
(<0.01)\end{array}$ & $\begin{array}{c}0.160 \\
(<0.01)\end{array}$ & $\begin{array}{c}0.054 \\
(<0.01)\end{array}$ & $\begin{array}{c}0.063 \\
(<0.01)\end{array}$ & $\begin{array}{c}-0.470 \\
(<0.01)\end{array}$ & & & & \\
\hline (13) Inhouse & $\begin{array}{c}0.129 \\
(<0.01)\end{array}$ & $\begin{array}{c}-0.123 \\
(<0.01)\end{array}$ & $\begin{array}{c}-0.092 \\
(<0.01)\end{array}$ & $\begin{array}{l}-0.024 \\
(0.12)\end{array}$ & $\begin{array}{c}0.035 \\
(0.02)\end{array}$ & $\begin{array}{c}-0.048 \\
(<0.01)\end{array}$ & $\begin{array}{c}-0.251 \\
(<0.01)\end{array}$ & $\begin{array}{c}-0.489 \\
(<0.01)\end{array}$ & $\begin{array}{c}-0.195 \\
(<0.01)\end{array}$ & $\begin{array}{l}-0.021 \\
(0.17)\end{array}$ & $\begin{array}{c}-0.117 \\
(<0.01)\end{array}$ & $\begin{array}{c}0.370 \\
(<0.01)\end{array}$ & $\begin{array}{c}-0.731 \\
(<0.01)\end{array}$ & & & \\
\hline (14) Indrel & $\begin{array}{l}-0.014 \\
(0.36)\end{array}$ & $\begin{array}{c}0.021 \\
(0.17)\end{array}$ & $\begin{array}{l}-0.007 \\
(0.66)\end{array}$ & $\begin{array}{c}-0.045 \\
(<0.01)\end{array}$ & $\begin{array}{l}-0.026 \\
(0.09)\end{array}$ & $\begin{array}{l}-0.005 \\
(0.75)\end{array}$ & $\begin{array}{c}0.054 \\
(<0.01)\end{array}$ & $\begin{array}{r}0.046 \\
(<0.01)\end{array}$ & $\begin{array}{c}0.106 \\
(<0.01)\end{array}$ & $\begin{array}{c}-0.061 \\
(<0.01)\end{array}$ & $\begin{array}{c}0.035 \\
(0.02)\end{array}$ & $\begin{array}{c}-0.061 \\
(<0.01)\end{array}$ & $\begin{array}{c}0.082 \\
(<0.01)\end{array}$ & $\begin{array}{c}-0.061 \\
(<0.01)\end{array}$ & & \\
\hline (15) Friendly & $\begin{array}{r}0.017 \\
(0.27)\end{array}$ & $\begin{array}{l}-0.021 \\
(0.18)\end{array}$ & $\begin{array}{c}-0.052 \\
(<0.01)\end{array}$ & $\begin{array}{l}-0.029 \\
(0.06)\end{array}$ & $\begin{array}{c}-0.048 \\
(<0.01)\end{array}$ & $\begin{array}{l}-0.010 \\
(0.51)\end{array}$ & $\begin{array}{c}0.022 \\
(0.14)\end{array}$ & $\begin{array}{c}-0.193 \\
(<0.01)\end{array}$ & $\begin{array}{c}0.058 \\
(<0.01)\end{array}$ & $\begin{array}{c}-0.059 \\
(<0.01)\end{array}$ & $\begin{array}{c}0.053 \\
(<0.01)\end{array}$ & $\begin{array}{c}0.134 \\
(<0.01)\end{array}$ & $\begin{array}{c}-0.136 \\
(<0.01)\end{array}$ & $\begin{array}{c}0.081 \\
(<0.01)\end{array}$ & $\begin{array}{l}-0.028 \\
(0.07)\end{array}$ & \\
\hline (16) Rel_Size & $\begin{array}{c}0.001 \\
(0.97)\end{array}$ & $\begin{array}{c}0.024 \\
(0.12)\end{array}$ & $\begin{array}{c}0.049 \\
(<0.01)\end{array}$ & $\begin{array}{c}0.010 \\
(0.53)\end{array}$ & $\begin{array}{l}-0.008 \\
(0.58)\end{array}$ & $\begin{array}{c}0.030 \\
(0.05)\end{array}$ & $\begin{array}{c}0.026 \\
(0.08)\end{array}$ & $\begin{array}{c}-0.151 \\
(<0.01)\end{array}$ & $\begin{array}{c}-0.068 \\
(<0.01)\end{array}$ & $\begin{array}{c}0.063 \\
(<0.01)\end{array}$ & $\begin{array}{c}-0.042 \\
(<0.01)\end{array}$ & $\begin{array}{c}-0.045 \\
(<0.01)\end{array}$ & $\begin{array}{c}-0.068 \\
(<0.01)\end{array}$ & $\begin{array}{r}0.087 \\
(<0.01)\end{array}$ & $\begin{array}{c}-0.064 \\
(<0.01)\end{array}$ & $\begin{array}{c}0.003 \\
(0.85)\end{array}$ \\
\hline
\end{tabular}

The sample consists of 4,283 U.S. mergers and acquisitions (listed in SDC) between 1988 and 2011 made by firms. P-values are shown in parentheses. Variable definitions are in the Appendix. 


\section{Acquirers' Abnormal Returns}

Table 3 shows that, on average, acquirers experience a positive market reaction to M\&A announcements. Note that our sample contains both public and private targets. Extant literature documents significantly positive returns in acquisitions of private targets and zero or negative returns in acquisitions of public targets. Our results are consistent with Masulis et al. (2007) and Fuller et al. (2002) who report positive returns on a combined sample of public and private targets. As expected, the market reaction is significantly greater for acquiring firms audited by industry specialists than acquiring firms audited by non-specialists. To remove the potential effect of audit firm size on the abnormal returns documented by Louis (2005) we compare abnormal returns after removing all non-Big N firms from the sample. The difference in the abnormal returns between industry specialists and non-specialists becomes even greater for the Big $\mathrm{N}$ only sample.

We next partition the data into several groups based on industry relatedness, target ownership status, deal payment method, the existence of investment banker, and analyst coverage. First, we condition our analysis on industry relatedness (Indrel). We find that acquirers with specialist auditors experience higher abnormal returns (significant at least at the five percent level) when the targets are in the same industry (i.e., Indrel=1). On the other hand, the differences in the mean and median abnormal returns for specialists' clients and non-specialists' clients are not significantly different from zero in the cross-industry acquisitions. This is consistent with our conjecture that industry specialists have a comparative advantage in providing M\&A advisory service and assurance of combined firms' financial statements using superior industry specific knowledge.

Table 3 also shows that industry specialists provide higher quality services when deals are complex. Specifically, the effect of specialists is greater when the target is a public company and uses more equity financing as a source of funding. Acquirers experience negative abnormal returns when their targets are public firms (i.e., Private $=0$ ). However, acquirers with specialist auditors experience significantly less negative returns indicating the effect of industry specialists is more pronounced in the acquisition of public targets. Acquirers of private targets on the other hand, experience positive abnormal returns; but, there is no statistical difference in the abnormal returns for the specialist and non-specialist groups. Acquirers with industry specialist auditors experience higher abnormal returns, when the proportion of stock financing (Stock) is greater.

Acquirers with industry specialist auditors experience lower negative abnormal returns, when the services of investment banks are used (i.e., Inhouse $=0$ ). ${ }^{16}$ Acquirers with industry specialist auditors experience higher abnormal returns when no investment bankers are identified in SDC suggesting that industry specialist auditors play a greater significant role when investment bankers are not present. Lastly, acquirers audited by industry specialists experience significantly higher abnormal returns when information asymmetry surrounding acquirers is large (i.e., low analyst coverage, Log(Analyst)<Median). Acquirers audited by industry specialists also experience significantly lower negative abnormal returns when information asymmetry is small.

These univariate comparisons generally support our predictions that industry specialists provide higher quality services when deals are complex (e.g., when the target is a public company and uses more equity financing as a source of funding), when the target is in the same industry, when investment bankers are not used, and there is greater uncertainty surrounding the acquisition. In sum, results in Table 3 show that clients of industry specialists are more likely to outperform clients of non-specialists when the likelihood of the industry specialist auditors playing a prominent role increases. In section 4.4, we provide more detailed tests using multivariate regressions.

\footnotetext{
${ }^{16}$ This result is consistent with the idea that industry specialists play more significant assurance, monitoring, and advisory roles when investment banks are not used. Alternatively, when investment banks are used, industry specialists deliver greater value to acquirers reducing negative returns. Investment banks are known to pressure clients to hire high quality auditors so that they have greater assurance that due diligence procedures have been complied with.
} 
Table 3. Univariate Analysis: Acquirers' Percentage Cumulative Abnormal Return

Around The Merger Announcement: Clients Of Industry Specialist Audit Firms Versus Clients Of Non-Specialist Audit Firms

\begin{tabular}{|c|c|c|c|c|c|c|c|c|c|c|c|}
\hline & \multicolumn{3}{|c|}{$\begin{array}{c}\text { (1) } \\
\text { Full sample }\end{array}$} & \multicolumn{3}{|c|}{$\begin{array}{c}(2) \\
\text { Specialists }\end{array}$} & \multicolumn{3}{|c|}{$\begin{array}{c}\text { (3) } \\
\text { Non-specialists }\end{array}$} & \multicolumn{2}{|c|}{ (2)-(3) } \\
\hline & $\mathbf{N}$ & Mean & Median & $\mathbf{N}$ & Mean & Median & $\mathbf{N}$ & Mean & Median & Mean & Median \\
\hline Full sample & 4283 & 0.426 & 0.105 & 1223 & 0.828 & .465 & 3060 & 0.265 & 0.020 & $0.563^{\text {**** }}$ & $0.446^{* *}$ \\
\hline Big4 Only & 3946 & 0.273 & 0.024 & 1217 & 0.783 & 0.400 & 2729 & 0.046 & -0.182 & $.737^{* * *}$ & $0.581^{* * * *}$ \\
\hline Within Indu & 2137 & 0.305 & 0.201 & 567 & 0.949 & 0.567 & 1570 & 0.072 & -0.024 & $0.877^{* * * *}$ & $0.591^{* * *}$ \\
\hline Cross Industry & 2146 & 0.546 & 0.065 & 656 & 0.723 & 0.380 & 1490 & 0.468 & 0.023 & 0.255 & 0.357 \\
\hline Public Target & 2394 & -0.986 & -0.744 & 707 & -0.312 & -0.027 & 1687 & -1.269 & \begin{tabular}{l|l|}
-0.954 \\
\end{tabular} & $0.957^{* * * * *}$ & 0.9 \\
\hline Private Target & 1889 & 2.215 & 1.483 & 516 & 2.390 & 1.174 & 1373 & 2.150 & 1.531 & 0.241 & -0.357 \\
\hline Stock M\&As & 2990 & 0.272 & \begin{tabular}{l|l|}
-0.018 \\
\end{tabular} & 814 & 0.814 & 0.250 & 2176 & 0.070 & \begin{tabular}{l|l|}
-0.158 \\
\end{tabular} & $0.744^{\text {*** }}$ & $0.408^{*}$ \\
\hline Cash & 1293 & 0.781 & 0.428 & 409 & 0.857 & 0.749 & 884 & 0.745 & 0.280 & 0.111 & 0.469 \\
\hline Inves & 2238 & -0.628 & -0.625 & 662 & -0.380 & -0.249 & 1576 & -0.733 & -0.766 & $0.352^{*}$ & 0.517 \\
\hline No Investment Banker & 2045 & 1.580 & 0.744 & 561 & 2.254 & 1.109 & 1484 & 1.325 & 0.549 & $0.929^{* * * *}$ & $0.560^{* * * *}$ \\
\hline & 2301 & 1.187 & 0.558 & 583 & 1.970 & 1.076 & 1718 & 0.921 & 0.390 & $1.048^{*}$ & $0.686^{*}$ \\
\hline High Analyst Coverage & 1982 & -0.458 & -0.318 & 640 & -0.212 & -0.077 & 1342 & -0.575 & -0.536 & $0.363^{\text {*** }}$ & $0.459^{* * *}$ \\
\hline
\end{tabular}

Column (1) reports full sample mean and median, and column (2) and (3) report the mean and median acquirers' percentage cumulative abnormal return around the merger announcement: full sample, clients of industry specialist audit firms, and clients of non-specialist audit firms, respectively. The last column reports the mean and median differences between clients of industry specialist audit firms and clients of non-specialist audit firms. *, **, and *** denote statistical significance at the 10 percent, 5 percent, and 1 percent levels, respectively, based on one-tailed tests.

\section{Regression Analyses of Industry Specialization on the Cumulative Abnormal Returns}

In Table 4, we report the results from our main regressions, controlling for all the bidder traits and deal characteristics. For brevity, intercepts and year dummies are not reported in Table 4. First, we replicate the main regression of Louis (2005) in regression (1) before we examine incremental effect of audit firm specialization. The coefficient estimate of BigN is -0.987 with a t-value of -1.70 , consistent with results documented in Louis (2005). Next we measure the effect of audit firm industry specialization in a reduced sample of 3,946 acquisitions after removing all non-Big $\mathrm{N}$ auditors. Consistent with our prediction the coefficient estimate of Audsp_TA is significantly positive with a t-value of 2.40 indicating that industry specialist auditors increase acquirer shareholder value.

Regression (3) and regression (6) are the main regressions that include industry specialization (Audsp_TA or $\left.A u d s p \_d u m\right)$ as well as $B i g N$. In both regressions, BigN continues to be negative and significant. In addition, we find that both Audsp_TA and Audsp_dum have significantly positive coefficients after controlling for BigN and bidder and deal characteristics. The coefficients suggest that increases to shareholder value are also economically significant. For example, the coefficient estimate of Audsp_dum in regression (6) is 0.772 with a t-statistic of 2.68, indicating that industry specialist auditors increase bidder shareholder value by about 0.772 percent which is a nontrivial number relative to the average acquisition announcement effect or ACAR of 0.426 percent.

In regression (4) and regression (7) we re-estimate the model after considering $B i g N$ auditor endogeneity. Specifically, we use Heckman's (1979) two-step procedure to ensure that announcement period return to the size of the audit firm is not driven by the determinants related to auditor choice. We add Lamda, the Inverse Mills Ratio from the Probit model below, to regression (4) and regression (7).

$$
\begin{aligned}
\text { BigN }_{i t} & =\mu_{0}+\mu_{1} L n\left(A c q_{-} T A\right)_{i t}+\mu_{2} A c q_{-} \text {Leverage }_{i t}+\mu_{3} A_{c q_{-}} \text {Cash }_{i t}+\mu_{4} \text { Ret_Vol }_{-}{ }_{i t} \\
& +\mu_{5} A c q_{-} E P_{i t}+\mu_{6} A c \text { Regind }_{i t}+\mu_{7} \text { SOX }_{i t}+\varepsilon_{i t} .
\end{aligned}
$$

Variable definitions are presented in Appendix.

In both estimation models, our variables for industry specialization remain to be significant. To alleviate this problem of cross-correlation in residuals, we add year fixed effect to all the regressions and use standard errors adjusted for firm-clustering. We also report as an additional robustness check, results using the Fama and MacBeth (1973) method. Specifically, we first run cross-sectional regressions for each year. Then, we report the time series 
averages of the coefficient estimates, and use the time-series standard errors of the average slope coefficients to draw inferences. The coefficient estimates and t-statistics from Fama and MacBeth (1973) regressions reported in regression (5) corroborate our findings using the pooled OLS regressions. ${ }^{17}$

With regard to our control variables, both the magnitude and statistical significance of the parameter estimates are fairly stable across the model specifications in Table 4. Most of the estimates for the control variables are consistent with the findings of Louis (2005). Specifically, we observe that $R O A$ has a significantly negative effect on acquirer returns. Stock is negatively and statistically significantly associated with ACAR supporting the idea that stock transactions signal to markets that bidding firms are in the possession of adverse private information. Cash_All is significant at the 10 percent level, which is also supportive of the above explanation. The coefficient on Private is positive and significant at the one percent level confirming that acquisitions of private firms elicit a more favorable market response. The coefficients of $N I B$ is negative and statistically significant. Similarly, acquirer returns are higher, although insignificantly, for acquisitions with no investment banker (Inhouse). Log(Tgt_TA) is significant at the 5 percent level, but inconsistent with the expected direction. Inconsistent with our expectation, the coefficients on $\log$ (Analyst) are negative although they are only marginally significant. An explanation is that analyst following is highly correlated with acquirer size which is negatively associated with abnormal returns. Finally, the coefficients on B/M, Pool, Inhouse, Indrel, Friendly, and Rel_Size are statistically insignificant.

In summary, the main results of interest namely, the coefficients on the industry specialization measures, are as predicted positive and statistically significant in all six models at least at the five percent level of testing. The results support the idea that industry specialists increase shareholder value of acquiring firms by providing higher quality assurance, monitoring, and possibly advisory services to their clients in M\&A transactions.

\section{Additional Analyses}

When is the Industry Specialization Effect Stronger?

The use of specialist-auditors involves higher costs to acquiring firms. As previously argued, however, we predict that benefits to the acquiring firm will likely exceed costs where the deals are complex, the amount of information asymmetry surrounding the acquirer is high, the target is in the same industry, and when investment bankers are not used. The univariate evidence in Table 3 generally supports our prediction. We additionally estimate the following multivariate regression model which includes five two-way interaction variables and a three-way interaction variable (i.e., Audsp $\times$ Stock, Audsp $\times$ Inhouse, Audsp $\times$ Private, Audsp $\times$ Log(Analyst), Audsp $\times$ Indrel, and Audsp $\times$ Inhousel $\times$ Stock).

$$
\begin{aligned}
& A C A R_{i t}=\beta_{0}+\beta_{1} \text { BigN }_{i t}+\beta_{2} A_{u d s p_{i t}}+\beta_{2-1} A_{u d s p_{i t}} \times \text { Stock }_{i t}+\beta_{2-2} A_{u d s p_{i t}} \times \text { Inhouse }_{i t} \\
& +\beta_{2-3} \text { Audsp }_{i t} \times \text { Inhouse }_{i t} \times \text { Stock }_{i t}+\beta_{2-4} \text { Audsp }_{i t} \times \text { Private }_{i t} \\
& +\beta_{2-5} \text { Audsp }{ }_{i t} \times \text { Indrel }_{i t}+\beta_{2-6} \text { Audsp }{ }_{i t} \times \log (\text { Analyst })_{i t} \\
& +\beta_{3} B / M_{i t}+\beta_{4} R O A_{i t}+\beta_{5} \log (\text { Analyst })+\beta_{6} \log \left(T g t_{-} T A\right)_{i t}+\beta_{7} \text { Stock }_{i t} \\
& +\beta_{8} \text { Cash_All }_{i t}+\beta_{9} \text { Pool }_{i t}+\beta_{10} \text { Private }_{i t}+\beta_{11} N I B_{i t}+\beta_{12} \text { Inhouse }_{i t} \\
& +\beta_{13} \text { Indrel }_{i t}+\beta_{14} \text { Friendly }_{i t}+\beta_{15} \text { Rel_Size }_{i t}+\text { year dummy }+\varepsilon_{i t,}
\end{aligned}
$$

Variable definitions are presented in Appendix. Audsp $p_{i t}$ is either Audsp_TA $A_{i t}$ or Audsp_dum ${ }_{i t}$.

$A u d s p \times$ Stock is expected to be positively related to abnormal returns because industry specialists can reduce information asymmetry where stock is used to finance a deal. The coefficient on Audsp_TAxInhouse is expected to be positive because industry specialists are expected to play a more significant role advising acquirers when investment bankers are not present. The coefficient on Audsp $\times$ Private is expected to be negative because we expect higher quality assurance, monitoring and advisory services from specialist auditors in acquisitions of public targets, which are more complex transactions. The coefficient on Audsp $\times$ Indrel is predicted to be positive because

\footnotetext{
${ }^{17}$ Note that the Fama-MacBeth methodology is a conservative way of accounting for potential cross-correlation in residuals. According to Fama and French (2002), Fama-MacBeth standard errors are often two to five times the OLS standard errors from pooled panel regressions that ignore cross-correlation.
} 
we expect a favorable market response to the use of industry specialist auditors in acquisitions of targets from a related industry. Audsp_TA $\times \log ($ Analyst) is expected to be negatively related to abnormal returns because the role of industry specialist auditors is expected to be more pronounced when there is greater information asymmetry surrounding the acquiring firm. Motivated by Louis (2005), we include a three-way interaction. Audsp $\times$ Inhouse $\times$ Stock is expected to be positive if industry specialist auditors play a more important role where investment bankers are not present and the deals are financed with a greater proportion of stock.

Table 5 summarizes the regression results. Consistent with the main results, our industry specialization measures (Audsp_TA and Audsp_dum) remain positive and significant even with the inclusion of the interaction variables. As expected, the coefficient on Audsp $\times$ Private is positive and statistically significant at least at the five percent level. Also the coefficient on Audsp_TA $\times \log ($ Analyst) is negative in the regression with Audsp_TA, but it is insignificant in the regression with Audsp_dum. The coefficient on Audsp $\times$ Stock is insignificant while that on Audsp $\times$ Inhouse $\times$ Stock is significantly positive. The coefficient on Audsp $\times$ Inhouse is insignificant indicating that the effect of industry specialist auditors is not pronounced in acquisitions financed by cash only.

The significantly positive coefficient on Audsp $\times$ Inhouse $\times$ Stock suggests that for all deals financed by equity either partially or fully industry specialists play a more significant role advising acquirers when investment bankers are not present. We find that the coefficient on Audsp $\times$ Indrel is not significant after controlling for other interaction effects, which suggests that the effect of industry specialists is not different between inter-industry and intra-industry M\&As. A possible reason is that there is relatively less information asymmetry in acquisitions between the firms in the same industry. The above results are hold, regardless of whether we control for BigN or not. We perform the same estimation on a reduced sample with only BigN acquirers and find (Untabulated) qualitatively similar results. 
Table 4. Baseline Regression Models

\begin{tabular}{|c|c|c|c|c|c|c|c|}
\hline & \multicolumn{7}{|c|}{ Dependent Variable $=A C A R$} \\
\hline & \multicolumn{5}{|c|}{ Audsp_TA } & \multicolumn{2}{|c|}{ Audsp_dum } \\
\hline & $\begin{array}{c}\text { (1) Louis (2005) } \\
\text { Model }\end{array}$ & $\begin{array}{l}\text { (2) BigN Only } \\
\text { Sample }\end{array}$ & $\begin{array}{c}\text { (3) Baseline } \\
\text { Model- } \\
\text { Continuous } \\
\text { Variable }\end{array}$ & $\begin{array}{l}\text { (4) Heckmann } \\
\text { Model }\end{array}$ & $\begin{array}{l}\text { (5) Fama- } \\
\text { Macbeth } \\
\text { Model }\end{array}$ & $\begin{array}{l}\text { (6) Dummy } \\
\text { Variable }\end{array}$ & $\begin{array}{c}\text { (7) Heckmann } \\
\text { Model }\end{array}$ \\
\hline BigN & $\begin{array}{l}-0.987 * * \\
(-1.70)\end{array}$ & & $\begin{array}{l}-1.555 * * * \\
(-2.52)\end{array}$ & $\begin{array}{l}-1.598 * * * \\
(-2.55)\end{array}$ & $\begin{array}{l}-0.988 \\
(-1.17)\end{array}$ & $\begin{array}{l}-1.202 * * \\
(-2.05)\end{array}$ & $\begin{array}{l}-1.247 * * \\
(-2.08)\end{array}$ \\
\hline$A u d s p \_T A$ & & $\begin{array}{l}3.316 * * * \\
(2.40)\end{array}$ & $\begin{array}{l}3.595 * * * \\
(2.67)\end{array}$ & $\begin{array}{l}3.598 * * * \\
(2.67)\end{array}$ & $\begin{array}{l}2.771 * * \\
(2.31)\end{array}$ & & \\
\hline Audsp_dum & & & & & & $\begin{array}{l}0.772 * * * \\
(2.68)\end{array}$ & $\begin{array}{l}0.773 * * * \\
(2.68)\end{array}$ \\
\hline$B / M$ & $\begin{array}{c}0.205 \\
(0.43)\end{array}$ & $\begin{array}{c}-0.111 \\
(-0.23)\end{array}$ & $\begin{array}{c}0.213 \\
(0.44)\end{array}$ & $\begin{array}{c}0.214 \\
(0.44)\end{array}$ & $\begin{array}{l}0.090 \\
(0.18)\end{array}$ & $\begin{array}{c}0.208 \\
(0.43)\end{array}$ & $\begin{array}{l}0.209 \\
(0.43)\end{array}$ \\
\hline$R O A$ & $\begin{array}{l}-2.863 * * * \\
(-2.41)\end{array}$ & $\begin{array}{l}-2.604 * * \\
(-2.07)\end{array}$ & $\begin{array}{l}-2.865 * * * \\
(-2.42)\end{array}$ & $\begin{array}{l}-2.888^{* * * *} \\
(-2.41)\end{array}$ & $\begin{array}{l}-2.038 \\
(-1.23)\end{array}$ & $\begin{array}{l}-2.850^{* *} \\
(-2.41)\end{array}$ & $\begin{array}{l}-2.875^{* * * *} \\
(-2.40)\end{array}$ \\
\hline $\log ($ Analyst $)$ & $\begin{array}{l}-0.176 \\
(-1.26)\end{array}$ & $\begin{array}{l}-0.279 * * \\
(-1.96)\end{array}$ & $\begin{array}{l}-0.182 * \\
(-1.30)\end{array}$ & $\begin{array}{l}-0.194^{*} \\
(-1.36)\end{array}$ & $\begin{array}{l}-0.310 * * \\
(-1.75)\end{array}$ & $\begin{array}{l}-0.202^{*} \\
(-1.44)\end{array}$ & $\begin{array}{l}-0.214^{*} \\
(-1.51)\end{array}$ \\
\hline $\log \left(T g t \_T A\right)$ & $\begin{array}{l}0.151 * * \\
(1.86)\end{array}$ & $\begin{array}{l}0.121^{*} \\
(1.48)\end{array}$ & $\begin{array}{l}0.150^{* *} \\
(1.85)\end{array}$ & $\begin{array}{l}0.141^{*} \\
(1.57)\end{array}$ & $\begin{array}{l}0.107 \\
(0.99)\end{array}$ & $\begin{array}{l}0.149 * * \\
(1.84)\end{array}$ & $\begin{array}{l}0.140^{*} \\
(1.56)\end{array}$ \\
\hline Stock & $\begin{array}{l}-0.019 * * * \\
(-4.27)\end{array}$ & $\begin{array}{l}-0.017 * * * \\
(-3.77)\end{array}$ & $\begin{array}{l}-0.019 * * * \\
(-4.21)\end{array}$ & $\begin{array}{l}-0.019 * * * \\
(-4.18)\end{array}$ & $\begin{array}{l}-0.021 * * * \\
(-3.56)\end{array}$ & $\begin{array}{l}-0.019 * * * \\
(-4.19)\end{array}$ & $\begin{array}{l}-0.019 * * * \\
(-4.16)\end{array}$ \\
\hline Cash_All & $\begin{array}{l}0.447 * \\
(1.42)\end{array}$ & $\begin{array}{l}0.582 * * \\
(1.83)\end{array}$ & $\begin{array}{l}0.465^{*} \\
(1.48)\end{array}$ & $\begin{array}{l}0.458^{*} \\
(1.44)\end{array}$ & $\begin{array}{l}0.809 \\
(0.69)\end{array}$ & $\begin{array}{l}0.459 * \\
(1.46)\end{array}$ & $\begin{array}{l}0.451 * \\
(1.42)\end{array}$ \\
\hline Pool & $\begin{array}{c}-0.095 \\
(-0.17)\end{array}$ & $\begin{array}{r}-0.313 \\
(-0.54)\end{array}$ & $\begin{array}{c}-0.078 \\
(-0.14)\end{array}$ & $\begin{array}{c}-0.087 \\
(-0.15)\end{array}$ & $\begin{array}{l}-0.595 \\
(-0.79)\end{array}$ & $\begin{array}{c}-0.079 \\
(-0.14)\end{array}$ & $\begin{array}{l}-0.088 \\
(-0.15)\end{array}$ \\
\hline Private & $\begin{array}{l}2.191 * * * \\
(6.46)\end{array}$ & $\begin{array}{l}2.091 * * * \\
(5.97)\end{array}$ & $\begin{array}{l}2.181 * * * \\
(6.42)\end{array}$ & $\begin{array}{l}2.195^{* * * *} \\
(6.32)\end{array}$ & $\begin{array}{l}1.563^{* * * *} \\
(5.42)\end{array}$ & $\begin{array}{l}2.177 * * * \\
(6.41)\end{array}$ & $\begin{array}{l}2.192 * * * \\
(6.31)\end{array}$ \\
\hline$N I B$ & $\begin{array}{l}-0.320 * * \\
(-2.14)\end{array}$ & $\begin{array}{l}-0.332 * * \\
(-2.17)\end{array}$ & $\begin{array}{l}-0.326 * * \\
(-2.18)\end{array}$ & $\begin{array}{l}-0.327 * * \\
(-2.18)\end{array}$ & $\begin{array}{l}-0.335 \\
(-1.20)\end{array}$ & $\begin{array}{l}-0.323 * * \\
(-2.15)\end{array}$ & $\begin{array}{l}-0.324 * * \\
(-2.16)\end{array}$ \\
\hline Inhouse & $\begin{array}{c}0.382 \\
(1.03)\end{array}$ & $\begin{array}{c}0.334 \\
(0.87)\end{array}$ & $\begin{array}{r}0.385 \\
(1.04)\end{array}$ & $\begin{array}{c}0.383 \\
(1.03)\end{array}$ & $\begin{array}{l}0.440 \\
(0.79)\end{array}$ & $\begin{array}{c}0.379 \\
(1.02)\end{array}$ & $\begin{array}{l}0.377 \\
(1.01)\end{array}$ \\
\hline Indrel & $\begin{array}{l}0.263 \\
(1.05)\end{array}$ & $\begin{array}{l}0.355^{*} \\
(1.38)\end{array}$ & $\begin{array}{c}0.287 \\
(1.15)\end{array}$ & $\begin{array}{c}0.286 \\
(1.14)\end{array}$ & $\begin{array}{l}0.545^{*} \\
(1.46)\end{array}$ & $\begin{array}{c}0.299 \\
(1.19)\end{array}$ & $\begin{array}{l}0.297 \\
(1.19)\end{array}$ \\
\hline Friendly & $\begin{array}{c}-0.178 \\
(-0.37)\end{array}$ & $\begin{array}{c}0.172 \\
(0.35)\end{array}$ & $\begin{array}{c}-0.168 \\
(-0.35)\end{array}$ & $\begin{array}{c}-0.172 \\
(-0.36)\end{array}$ & $\begin{array}{l}-0.184 \\
(-0.26)\end{array}$ & $\begin{array}{l}-0.161 \\
(-0.33)\end{array}$ & $\begin{array}{l}-0.166 \\
(-0.34)\end{array}$ \\
\hline $\begin{array}{l}\text { Rel_Size } \\
\text { Lambda }\end{array}$ & $\begin{array}{c}0.000 \\
(0.92)\end{array}$ & $\begin{array}{c}0.000 \\
(0.47)\end{array}$ & $\begin{array}{c}0.000 \\
(0.86)\end{array}$ & $\begin{array}{c}0.000 \\
(0.70) \\
-0.299 \\
(-0.21) \\
\end{array}$ & $\begin{array}{l}-0.000 \\
(-0.89)\end{array}$ & $\begin{array}{c}0.000 \\
(0.95)\end{array}$ & $\begin{array}{l}0.000 \\
(0.78) \\
-0.318 \\
(-0.22) \\
\end{array}$ \\
\hline $\begin{array}{l}\text { Year Fixed } \\
\text { effect }\end{array}$ & Yes & Yes & Yes & Yes & No & Yes & Yes \\
\hline Observations & 4,283 & 3,946 & 4,283 & 4,283 & 4,283 & 4,283 & 4,283 \\
\hline $\begin{array}{l}\text { Adj. R- } \\
\text { squared }\end{array}$ & 0.068 & 0.068 & 0.069 & 0.069 & 0.040 & 0.069 & 0.069 \\
\hline
\end{tabular}


Table 5. When Is Industry Specialist Effect Stronger?

\begin{tabular}{|c|c|c|}
\hline & \multicolumn{2}{|c|}{ Dependent Variable $=A C A R$} \\
\hline & Audsp=Audsp_TA & Audsp=Audsp_dum \\
\hline \multirow[t]{2}{*}{$B i g N$} & $-1.684 * * *$ & $-1.233^{* *}$ \\
\hline & $(-2.75)$ & $(-2.12)$ \\
\hline \multirow[t]{2}{*}{ Audsp } & $10.275 * * *$ & $1.449 * *$ \\
\hline & $(2.78)$ & $(1.79)$ \\
\hline \multirow{2}{*}{ Audsp $\times$ Stock } & -0.032 & -0.009 \\
\hline & $(-0.96)$ & $(-1.08)$ \\
\hline \multirow[t]{2}{*}{ Audsp $\times$ Inhouse } & -2.439 & -0.157 \\
\hline & $(-0.90)$ & $(-0.24)$ \\
\hline \multirow{2}{*}{ Audsp $\times$ Inhouse $\times$ Stock } & $0.126 * * *$ & $0.043 * * *$ \\
\hline & $(3.96)$ & $(3.27)$ \\
\hline \multirow[t]{2}{*}{ Audsp $\times$ Private } & $-4.922 * *$ & $-1.225 * *$ \\
\hline & $(-1.80)$ & $(-2.01)$ \\
\hline \multirow[t]{2}{*}{ Audsp $\times$ Indrel } & 0.982 & 0.572 \\
\hline & $(0.43)$ & $(1.04)$ \\
\hline \multirow{2}{*}{ Audsp $\times \log ($ Analyst $)$} & $-2.692 * *$ & -0.308 \\
\hline & $(-2.19)$ & $(-1.11)$ \\
\hline \multirow[t]{2}{*}{$B / M$} & 0.257 & 0.200 \\
\hline & $(0.53)$ & $(0.42)$ \\
\hline \multirow[t]{2}{*}{$R O A$} & $-2.893 * * *$ & $-2.874 * * *$ \\
\hline & $(-2.40)$ & $(-2.41)$ \\
\hline \multirow[t]{2}{*}{ Log(Analyst) } & 0.356 & -0.117 \\
\hline & $(1.20)$ & $(-0.71)$ \\
\hline \multirow{2}{*}{$\log \left(T g t \_T A\right)$} & $0.154 * *$ & $0.155 * *$ \\
\hline & $(1.91)$ & $(1.91)$ \\
\hline \multirow[t]{2}{*}{ Stock } & $-0.023 * * *$ & $-0.022 * * *$ \\
\hline & $(-3.06)$ & $(-4.42)$ \\
\hline \multirow[t]{2}{*}{ Cash_All } & 0.313 & 0.355 \\
\hline & $(1.00)$ & (1.13) \\
\hline \multirow[t]{2}{*}{ Pool } & 0.109 & 0.084 \\
\hline & $(0.19)$ & $(0.15)$ \\
\hline \multirow[t]{2}{*}{ Private } & $3.066 * * *$ & $2.466 * * *$ \\
\hline & $(4.97)$ & $(6.35)$ \\
\hline \multirow[t]{2}{*}{$N I B$} & $-0.335 * *$ & $-0.328 * *$ \\
\hline & $(-2.24)$ & $(-2.19)$ \\
\hline \multirow[t]{2}{*}{ Inhouse } & 0.171 & 0.117 \\
\hline & $(0.27)$ & $(0.28)$ \\
\hline \multirow[t]{2}{*}{ Indrel } & 0.109 & 0.148 \\
\hline & $(0.21)$ & $(0.49)$ \\
\hline \multirow[t]{2}{*}{ Friendly } & 0.011 & -0.034 \\
\hline & $(0.02)$ & $(-0.07)$ \\
\hline \multirow[t]{2}{*}{ Rel_Size } & 0.000 & 0.000 \\
\hline & $(0.97)$ & $(0.96)$ \\
\hline Year Fixed effect & Yes & Yes \\
\hline Observations & 4,283 & 4,283 \\
\hline Adj. R-squared & 0.075 & 0.074 \\
\hline
\end{tabular}

Notes: $* * *, * *$, and $*$ represent significance at the 1,5 , and 10 percent level in a one-tail test, respectively. T-values are based on standard errors adjusted for heteroskedasticity and firm clustering (Petersen 2009). Variable definitions are presented in Appendix.

\section{Alternative Measures of Audit firm Industry Specialization}

In this section, we perform sensitivity tests for four alternative measures of audit firm industry specialization. Following the industry specialization literature we use the following measures of audit firm specialization: Audsp_Sale, Audsp_Client, Leader, and Dominance. Audsp_Sale is the market share of the auditor measured in client sales in a two-digit industry (Balsam et al. 2003). Audsp_Client is defined as the market share of the auditor measured in the number of clients in a two-digit industry (Balsam et al. 2003). Leader is a binary variable that is equal to 1 for industry specialists, 0 otherwise where industry specialists are identified as the largest 
auditor in each industry, as well as the second- and third-largest auditors in industries (Balsam et al. 2003). Dominance is a binary variable that is equal to 1 if the auditing firm is the largest supplier of audit services and its market share is at least 10 percent greater than that of the second supplier, 0 otherwise (Balsam et al. 2003).

Results reported in Table 6 are generally consistent with industry specialist auditors enhancing acquirer value on the announcement of mergers and acquisitions. Among the four industry specialization proxies, Audsp_Sale provides the most statistically significant association with stock market returns $(\mathrm{t}-\mathrm{value}=2.92)$. All of remaining measures, excepting for Leader, provide qualitatively similar results. We also perform the regression estimation on a reduced sample with only Big $\mathrm{N}$ acquirers we find (Untabulated) qualitatively similar results.

Table 6. Robustness Tests: Alternative Specialization Measures

\begin{tabular}{|c|c|c|c|c|}
\hline & \multicolumn{4}{|c|}{ Dependent Variable $=A C A R$} \\
\hline & Audsp_Sale & Leader & Dominance & Audsp_Client \\
\hline$B i g N$ & $\begin{array}{c}-1.610 * * * \\
(-2.60)\end{array}$ & $\begin{array}{c}-1.217 * * \\
(-2.00)\end{array}$ & $\begin{array}{c}-1.101 * * \\
(-1.89)\end{array}$ & $\begin{array}{c}-1.214 * * \\
(-2.06)\end{array}$ \\
\hline Audsp_Sale & $\begin{array}{c}3.969 * * * \\
(2.92)\end{array}$ & & & \\
\hline Leader & & $\begin{array}{c}0.371 \\
(1.23)\end{array}$ & & \\
\hline Dominance & & & $\begin{array}{c}0.928 * * \\
(2.39)\end{array}$ & \\
\hline Audsp_Client & & & & $\begin{array}{c}4.557 * * * \\
(2.64)\end{array}$ \\
\hline$B / M$ & $\begin{array}{l}0.213 \\
(0.44)\end{array}$ & $\begin{array}{c}0.206 \\
(0.43)\end{array}$ & $\begin{array}{c}0.224 \\
(0.47)\end{array}$ & $\begin{array}{c}0.218 \\
(0.45)\end{array}$ \\
\hline$R O A$ & $\begin{array}{c}-2.883 * * * \\
(-2.43)\end{array}$ & $\begin{array}{c}-2.852 * * * \\
(-2.40)\end{array}$ & $\begin{array}{c}-2.846^{* * *} \\
(-2.39)\end{array}$ & $\begin{array}{c}-2.843 * * * \\
(-2.40)\end{array}$ \\
\hline $\log ($ Analyst $)$ & $\begin{array}{c}-0.181^{*} \\
(-1.30)\end{array}$ & $\begin{array}{l}-0.182^{*} \\
(-1.30)\end{array}$ & $\begin{array}{c}-0.174 \\
(-1.24)\end{array}$ & $\begin{array}{l}-0.168 \\
(-1.20)\end{array}$ \\
\hline $\log \left(T g t \_T A\right)$ & $\begin{array}{c}0.147 * * \\
(1.81)\end{array}$ & $\begin{array}{c}0.146^{* *} \\
(1.80)\end{array}$ & $\begin{array}{c}0.143 * * \\
(1.76)\end{array}$ & $\begin{array}{c}0.150 * * \\
(1.86)\end{array}$ \\
\hline Stock & $\begin{array}{c}-0.019 * * * \\
(-4.22)\end{array}$ & $\begin{array}{c}-0.019 * * * \\
(-4.24)\end{array}$ & $\begin{array}{c}-0.019 * * * \\
(-4.22)\end{array}$ & $\begin{array}{c}-0.019 * * * \\
(-4.21)\end{array}$ \\
\hline Cash_All & $\begin{array}{c}0.468 * \\
(1.48)\end{array}$ & $\begin{array}{l}0.446^{*} \\
(1.41)\end{array}$ & $\begin{array}{l}0.473 * \\
(1.50)\end{array}$ & $\begin{array}{l}0.455^{*} \\
(1.44)\end{array}$ \\
\hline Pool & $\begin{array}{l}-0.078 \\
(-0.14)\end{array}$ & $\begin{array}{l}-0.100 \\
(-0.18)\end{array}$ & $\begin{array}{r}-0.085 \\
(-0.15)\end{array}$ & $\begin{array}{l}-0.089 \\
(-0.16)\end{array}$ \\
\hline Private & $\begin{array}{c}2.177 * * * * \\
(6.41)\end{array}$ & $\begin{array}{c}2.184 * * * \\
(6.42)\end{array}$ & $\begin{array}{c}2.183 * * * \\
(6.44)\end{array}$ & $\begin{array}{c}2.186^{* * * *} \\
(6.44)\end{array}$ \\
\hline$N I B$ & $\begin{array}{c}-0.327 * * \\
(-2.19)\end{array}$ & $\begin{array}{c}-0.320 * * \\
(-2.14)\end{array}$ & $\begin{array}{c}-0.315^{* *} \\
(-2.10)\end{array}$ & $\begin{array}{c}-0.320 * * \\
(-2.15)\end{array}$ \\
\hline Inhouse & $\begin{array}{l}0.382 \\
(1.03)\end{array}$ & $\begin{array}{c}0.386 \\
(1.04)\end{array}$ & $\begin{array}{c}0.392 \\
(1.05)\end{array}$ & $\begin{array}{r}0.397 \\
(1.07)\end{array}$ \\
\hline Indrel & $\begin{array}{l}0.293 \\
(1.17)\end{array}$ & $\begin{array}{r}0.273 \\
(1.09)\end{array}$ & $\begin{array}{c}0.284 \\
(1.13)\end{array}$ & $\begin{array}{r}0.285 \\
(1.14)\end{array}$ \\
\hline Friendly & $\begin{array}{l}-0.174 \\
(-0.36)\end{array}$ & $\begin{array}{l}-0.185 \\
(-0.38)\end{array}$ & $\begin{array}{r}-0.187 \\
(-0.39)\end{array}$ & $\begin{array}{l}-0.180 \\
(-0.37)\end{array}$ \\
\hline Rel_Size & $\begin{array}{l}0.000 \\
(0.82)\end{array}$ & $\begin{array}{c}0.000 \\
(0.87)\end{array}$ & $\begin{array}{r}0.000 \\
(0.85)\end{array}$ & $\begin{array}{r}0.000 \\
(0.97)\end{array}$ \\
\hline Year Fixed Effect & Yes & Yes & Yes & Yes \\
\hline Observations & 4,283 & 4,283 & 4,283 & 4,283 \\
\hline Adj. R-squared & 0.070 & 0.068 & 0.069 & 0.069 \\
\hline
\end{tabular}

Notes: Dominance is a binary variable that is equal to 1 if the auditing firm is the largest supplier of audit services and its market share is at least 10 percent greater than that of the second supplier (Balsam et al. 2003), 0 otherwise; Leader is a binary variable that is equal to 1 for industry specialists, 0 otherwise. Industry specialists are identified as the largest auditor in each industry, as well as the second- and third-largest auditors in industries (Balsam et al. 2003); Audsp_Client is defined as the market share of the auditor measured in the number of clients in a two-digit industry (Balsam et al. 2003); Audsp_Sale is the market share of the auditor measured in client sales in a two-digit industry (Balsam et al. 2003). Other variable definitions are in Appendix 1. ***,**, and * represent significance at the 1, 5, and 10 percent level in a one-tail test, respectively. T-values are based on standard errors adjusted for heteroskedasticity and firm clustering (Petersen 2009). Variable definitions are presented in Appendix. 


\section{CONCLUSION}

In this study, we posit that industry specialists provide higher quality assurance, monitoring and advisory services to their audit clients involved in acquisitions. Specifically, we examine whether the stock market reaction is higher to announcements of mergers and acquisitions of acquirers audited by industry specialists. The only study we are aware of that has examined the effect of external auditor choice on stock prices of acquirers around merger announcements is Louis (2005). He finds that acquirers audited by non-Big 4 accounting firms experience higher abnormal returns, supporting his hypothesis that non-Big 4 auditors possess superior knowledge of the local markets in which their clients make their acquisitions.

In contrast to Louis, we examine differences in audit quality between industry specialist and non-specialist auditors. Louis results are limited to explaining variation in a relatively small percentage of the M\&A deals. Specifically, the non-Big 4 only audit about 5 percent of all M\&A acquisitions. Our study contributes to the literature because we study variation in abnormal returns within the remaining 95 percent of M\&A deals. Our results show that the stock market reaction is more positive when the acquirer is audited by an industry specialist. This suggests that greater assurance and monitoring values provided by industry specialist audit firms. Consistent with expectations, we also find that markets perceive the value of industry specialist auditors to be greater when target firms are publicly traded, when the M\&As rely more on stock financing, and there when no investment bankers are present and stock financing is used.

While there has been extensive research on mergers and acquisitions, there is still a lot to be understood about the value of these deals to investors. A significant amount of the stock market variation to announcements of M\&A transactions has yet to be explained by research. This study informs investors, regulators, investment bankers and practitioners on how the choice of an auditor affects shareholder wealth in mergers and acquisitions, which undoubtedly are very important events in the corporate finance world. Future work is needed on increasing our understanding of whether other measures of auditor expertise, for example auditor tenure, are useful in explaining stock market returns surrounding these events.

\section{ACKNOWLEDGEMENTS}

This work was supported by the Korea Research Foundation Grant funded by the Korean Government (NRF2012S1A2A1A01031176).

\section{AUTHOR INFORMATION}

Prof. Ho-Young Lee, Ph.D. University of Oregon. Prof. Lee has taught accounting in Yonsei University and the University of Nebraska-Omaha. Please direct all correspondence to Ho-Young Lee, 50 Yonsei-ro, Seodaemun-gu, School of Business, Yonsei University, Seoul, S. Korea. Tel: (+822) 2123-5484 E-mail: hylee@ yonsei.ac.kr

Prof. Vivek Mande, Ph.D. University of California, Los Angeles. Prof. Mande has taught accounting in California State University, Fullerton, the University of Nebraska, Omaha, the City University of New York- Baruch, and the University of Arizona. E-mail: vmande@ fullerton.edu

Prof. Jong Chool Park, Ph.D. Carnegie Mellon University. Prof. Park has taught accounting in Old Dominion University and Rensselaer Polytechnic Institute. E-mail: jcpark@odu.edu

\section{REFERENCES}

Abbott, L., Parker, S., and G. Peters. (2006). Earnings management, litigation risk, and asymmetric audit fee responses. Auditing: A Journal of Practice \& Theory 25 (1): 85-98.

Asquith, P., Bruner, R., and D. Mullins. (1983). The gains to bidding firms. Journal of Financial Economics 11: 121-139.

Agrawal, A., Jaffe, J., and G. Mandelker. (1992). The post-merger performance of acquiring firms: A reexamination of an anomaly. Journal of Finance 47: 1605-1621. 
Ahmed, A., Rasmussen, S., and S. Tse. (2008). Audit quality, alternative monitoring mechanisms, and cost of capita: an empirical analysis. Texas A\&M University. Working paper.

Balsam, S., Krishnan, J., and J. Yang. (2003). Auditor industry specialization and earnings quality. Auditing: A Journal of Practice \&Theory 22 (2): 71-97.

Balvers, R., McDonald, B., and R. Miller. (1988). Underpricing of new issues and the choice of auditor as a signal of investment banker reputation. The Accounting Review 6 (October): 605-622.

Beatty, R. (1989). Auditor reputation and the pricing of initial public offerings. The Accounting Review 64 (3): $693-$ 709.

Behn, B., Choi, J., and T. Kang. (2008). Audit quality and properties of analyst earnings forecasts. The Accounting Review 83 (2): 327-349.

Bradley, M., Desai, A., and H. Kim. (1988). Synergistic gains from corporate acquisitions and their division between the stockholders of target and acquiring firms. Journal of Financial Economics 21: 3-40.

Chang, S. (1998). Takeovers of privately held targets, method of payment and bidder returns. Journal of Finance 53: 773-784.

Craswell, A., Francis, J., and S. Taylor. (1995). Auditor brand name reputation and industry specialization. Journal of Accounting and Economics 20: 297-322.

Dodd, P., and R. Ruback. (1977). Tender offers and stockholder returns: an empirical analysis. Journal of Financial Economics 5: 351-374.

Dunn, K., and B. Mayhew. (2004). Audit firm industry specialization and client disclosure quality. Review of Accounting Studies 9: 35-58.

Erickson, M., Wang, S., and F. Zhang. (2012). The change in information uncertainty and acquirer wealth losses. Review of Accounting Studies 17 (4): 1-31.

Fama, E., and J. MacBeth. (1973). Risk, return, and equilibrium: Empirical tests. Journal of Political Economy 81: $607-636$.

Fama, E., and K. French. (2002). The Equity premium. The Journal of Finance, 57: 637-659.

Fleming, D., and R. Romanus. (2007). Auditor industry specialization and audit fees surrounding Section 404 implementation. Working paper. San Diego State and Texas Tech University.

Fuller, K., Netter, J., and M. Stegemoller. (2002). What do returns to acquiring firms tell us? Evidence from firms that make many acquisitions. Journal of Finance 57: 1763-1794.

GAO. (2008). Audits of Public Companies: continued concentration in audit market for large public companies does not does not call for immediate action. United States Government Accountability Office. Washington D.C.

Godfrey, J., and J. Hamilton. (2005). The impact of R\&D intensity on demand for specialist auditor services. Contemporary Accounting Research 22 (1): 55-93.

Golubov, A., D. Petmezas, T. Sougiannis, and N. Travlos. (2011). Target firm auditor reputation, information asymmetry, and corporate takeovers. Working Paper. City University of London, University of Surrey, University of Illinois.

Gul, F., S. Fung, and B. Jaggi., (2009). Earnings quality: some evidence on the role of auditor tenure and auditors' industry expertise. Journal of Accounting and Economics 47: 265-287.

Hammersley, J. (2006). Pattern identification and industry specialist auditors. The Accounting Review 81(2): 309336.

Healy, P., Krishna, M., Palepu, G., and R. Ruback. (1992). Does corporate performance improve after merger? Journal of Financial Economics 31: 135-175.

Hogan, C., and D. Jeter. (1999). Industry specialization by auditors. Auditing: A Journal of Practice \& Theory 18(spring): 1-17.

Jenkins, D., Kane, G., and U. Velury. (2006). Earnings quality decline and the effect of industry specialist auditors: an analysis of the late 1990s. Journal of Accounting Public Policy 25: 71-90.

Jensen, M., and R. Ruback. (1983). The market for corporate control: the scientific evidence. Journal of Financial Economics 11: 5-50.

Kwon, S., Lim, C., and P. Tan. (2007). Legal systems and earnings quality: the role of auditor industry specialization. Auditing: A Journal of Practice \& Theory 26 (2): 25-55.

Loughran, T., and A. Vijh. (1997). Do long-term shareholders benefit from corporate acquisitions? Journal of Finance 52: 1765-1790. 
Louis, H. (2004). Earnings management and the market performance of acquiring firms. Journal of Financial Economics 74: 121-148.

Louis, H. (2005). Acquirers' abnormal returns and the non-Big4 auditor clientele effect. Journal of Accounting and Economics 40: 75-99.

Lys, T., and Vincent. (1995). An analysis of value destruction in AT\&T's acquisition of NCR. Journal of Financial Economics 39: 353-378.

Manne, H. (1965). Mergers and the market for corporate control. Journal of Political Economy 75: 110-120.

Masulis, R., Wang, C., and F. Xie. (2007). Corporate governance and acquirer returns. The Journal of Finance LXII (4): 1851-1889.

Mayhew, B., Wilkins, M., (2003). Audit firm industry specialization as a differentiation strategy: evidence from fees charged to firms going public. Auditing: A Journal of Practice \& Theory 22 (2), 33-52.

Moeller, S., Schlingemann, F., and R. Stulz. (2004). Firm size and the gains from acquisitions. Journal of Financial Economics 73: 201 - 228.

Morck, R., Shleifer, A.,and R. Vishny. (1990). Do managerial objectives drive bad acquisitions? Journal of Finance 45: 31-48.

Moeller, S., Schlingemann, F., and R. Stulz. (2005). Wealth destruction on a massive scale: A study of acquiring firm returns in the merger wave of the late 1990's. Journal of Finance 60: 757-782.

Myers, S., and N. Majluf. (1984). Corporate financing and investment decisions when firms have information that investors do not have. Journal of Financial Economics 12: 187-222.

Owhoso, V., Messier, W., and J. Lynch. (2002). Error detection by industry specialized teams during sequential audit review. Journal of Accounting Research 40 (June): 883-900.

Pandit, S. (2006). Accounting choice and operating performance in stock-for-stock mergers. Working paper. University of Rochester.

Petersen, M. (2009). Estimating standard errors in finance panel data sets: Comparing approaches," Review of Financial Studies 22: 435-480.

Rau, R., and T. Vermaelen. (1998). Glamour, value and the post-acquisition performance of acquiring firms. Journal of Financial Economics 49: 223-253.

Salavei, K., and N. Moore. (2005). Signals sent by financial statement restatements. Working paper. University of Connecticut.

Scanlon, K., Trifts, J., and R. Pettway. 1989. Impacts of relative size and industrial relatedness on returns to shareholders of acquiring firms. Journal of Financial Research 12: 103-112.

Schwert, G. (2000). Hostility in takeovers: in the eyes of the beholder? Journal of Finance 55: 2599-2640.

Servaes, H., and M. Zenner. (1996). The role of investment banks in acquisitions. Review of Financial Studies 9: 787-815.

Seth, A. (1990). Value creation in acquisitions: a re-examination of performance issues. Strategic Management Journal 11: 99-115.

Singh, H., and C. Montgomery. (1987). Corporate acquisition strategies and economic performance. Strategic Management Journal 8 (4): 377-386.

Solomon, I., Shields, M., and O. Whittington. (1999). What do industry specialist auditors know? Journal of Accounting Research 37 (spring): 191-208.

Travlos, N. (1987). Corporate takeover bids, methods of payment, and bidding firms' stock returns. Journal of Finance 42: 943-963.

Willenborg, M. (1999). Empirical analysis of the economic demand for auditing in the initial public offerings market. Journal of Accounting Research (spring): 225-238.

Xie, Y., H. Yi, and Y. Zhang. (2013). The value of Big N target auditors in corporate takeovers. Auditing: A Journal of Practice \& Theory 32 (3): 141-169. 


\section{APPENDIX}

\begin{tabular}{|c|c|c|}
\hline \multirow[b]{2}{*}{$A C A R$} & & \\
\hline & $=$ & $\begin{array}{l}\text { percentage cumulative abnormal return of the bidder computed over the day of the merger } \\
\text { announcement, the preceding day, and the day after }(\mathrm{t}=[-2,2]) \text {; }\end{array}$ \\
\hline BigN & $=$ & $\begin{array}{l}\text { a binary variable that is equal to one for clients of Big N audit firms and zero for clients of non- } \\
\text { Big N firms; }\end{array}$ \\
\hline Audsp_TA & $=$ & the market share of the auditor $i$ in industry $k$ \\
\hline Audsp_dum & $=$ & $\begin{array}{l}\text { a binary variable that is equal to } 1 \text { if } A u d s p_{-} T A \text { is greater than } 20 \text { percent during 1988-1997 (Big } \\
6 \text { regime), } 25 \text { percent during 1998-2000 (Big } 5 \text { regime), and } 30 \text { percent during 2001-2011 (Big } 4 \\
\text { regime), } 0 \text { otherwise; }\end{array}$ \\
\hline Dominance & $=$ & $\begin{array}{l}\text { a binary variable that is equal to } 1 \text { if the auditing firm is the largest supplier of audit services and } \\
\text { its market share is at least } 10 \text { percent greater than that of the second supplier (Balsam et al. } \\
\text { 2003), } 0 \text { otherwise; }\end{array}$ \\
\hline Leader & $=$ & $\begin{array}{l}\text { a binary variable that is equal to } 1 \text { for industry specialists, } 0 \text { otherwise, where industry } \\
\text { specialists are identified as the largest auditor in each industry, as well as the second- and third- } \\
\text { largest auditors in industries (Balsam et al. 2003); }\end{array}$ \\
\hline Audsp_Client & $=$ & $\begin{array}{l}\text { the market share of the auditor measured in the number of clients in a two-digit industry } \\
\text { (Balsam et al. 2003); }\end{array}$ \\
\hline Audsp_Sale & $=$ & $\begin{array}{l}\text { the market share of the auditor measured in client sales in a two-digit industry (Balsam et al. } \\
2003 \text { ); }\end{array}$ \\
\hline$B / M$ & $=$ & acquirer's book-to-market ratio; \\
\hline$R O A$ & $=$ & acquirer's return-on-assets; \\
\hline Log(Analyst) & $=$ & $\begin{array}{l}\text { analyst coverage, measured by natural logarithm of the number of analysts forecasting the } \\
\text { acquirer's annual earnings in the month immediately prior to the earnings announcement; }\end{array}$ \\
\hline $\log \left(T g t \_T A\right)$ & $=$ & the natural logarithm of the target's total assets; \\
\hline Stock & $=$ & percentage of the transaction financed with common stock; \\
\hline Cash_All & $=$ & $\begin{array}{l}\text { a binary variable that is equal to one if the merger is financed entirely with cash and zero } \\
\text { otherwise; }\end{array}$ \\
\hline Pool & $=$ & $\begin{array}{l}\text { a binary variable taking the value one if the merger is accounted for by the pooling-of-interest } \\
\text { method and zero if it is accounted for by the purchase method; }\end{array}$ \\
\hline Private & $=$ & a binary variable taking the value one is the target is a private company and zero otherwise; \\
\hline$N I B$ & $=$ & $\begin{array}{l}\text { a proxy for the industry relatedness of the merging firms, is equal to one if the two merging } \\
\text { partners are in the same three-digit SIC code and zero otherwise; }\end{array}$ \\
\hline Inhouse & $=$ & $\begin{array}{l}\text { a binary variable taking the value one if no investment banker is identified by SDC and zero } \\
\text { otherwise; }\end{array}$ \\
\hline Indrel & $=$ & $\begin{array}{l}\text { a proxy for the industry relatedness of the merging firms, is equal to one if the two merging } \\
\text { partners are in the same three-digit SIC code and zero otherwise; }\end{array}$ \\
\hline Friendly & $=$ & $\begin{array}{l}\text { one if the target's attitude to the proposed merger is characterized as friendly by SDC, and zero } \\
\text { otherwise; }\end{array}$ \\
\hline Rel_Size & $=$ & relative size, is the ratio of the acquirer's total assets to the target's total assets; and \\
\hline Lambda & $=$ & $\begin{array}{l}\text { the inverse Mills ratio from the Probit model below. } \\
\text { BigN }_{i t}=\mu_{0}+\mu_{1} L n\left(A c q_{-} T A\right)_{i t}+\mu_{2} A c \text { Leverage }_{i t}+\mu_{3} A c q_{-} \text {Cash }_{i t} \\
+\mu_{4} \text { Ret_Vol }_{i t}+\mu_{5} A c q_{-} E P_{i t}+\mu_{6} A c q_{-} \text {Regind }_{i t}+\mu_{7} S O X_{i t}+\varepsilon_{i t} .\end{array}$ \\
\hline & & $\begin{array}{l}\text { where, } \operatorname{Ln}\left(A c q_{-} T A\right)_{i t} \text { is the natural logarithm of the acquirer's total assets (in million); } \\
\text { Acq_Leverage } e_{i t} \text { is the acquirer's leverage defined as total liabilities divided by total assets; } \\
\text { Acq_Cash } h_{i t} \text { is the acquirer's cash divided by total assets; } A c q_{-} E P_{i t} \text { is the acquirer's earnings-to- } \\
\text { price ratio; Ret_Vol } \text { it }_{i t} \text { is a measure of the acquirer's pre-merger stock volatility proxied by the } \\
\text { standard deviation of the acquirer's return over the period from } 60 \text { to } 259 \text { days before the merger } \\
\text { announcement; } A c q_{-} \text {Regind } d_{i t} \text { is a binary variable taking the value one if the acquirer is in a } \\
\text { regulated industry (SIC } 60-69 \text {, and } 49 \text { ) and zero otherwise; and } S O X_{i t} \text { is a binary variable taking } \\
\text { the value one if the announcement is made in } 2003-2011 \text { and zero otherwise. }\end{array}$ \\
\hline
\end{tabular}

\section{Variable Definition}


NOTES 